

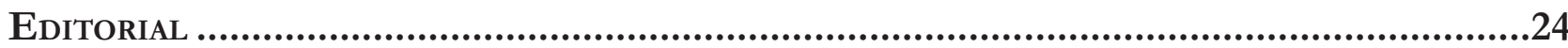

O Direito na fronteira da razão: Psicologia, neurociência e economia comportamental................... 24 Patrícia Perrone Campos Mello e Sergio Nojiri

I. NeURodireito: COGNIÇão, EMOÇÃo, JUÍZOS MORAIS E CIÊNCIA ..........................................26

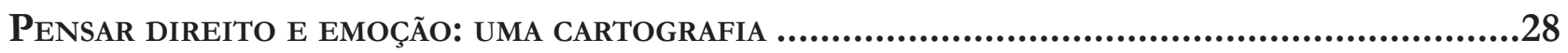

Nevita Maria Pessoa de Aquino Franca Luna

Neurodireito: o início, o fim E O MEIO

Carlos Marden e Leonardo Martins Wykrota

ENSAIO JURÍDICO SOBRE A RACIONALIDADE HUMANA: MAIORES, CAPAZES E IRRACIONAIS

André Perin Schmidt Neto e Eugênio Facchini Neto

DIVERGÊNCIAS DE PRINCÍPIO: ARGUMENTOS JURÍDICOS E MORAIS EM UM CENÁRIO DE DESACORDOS SOCIAIS

André Matos de Almeida Oliveira, Pâmela de Rezende Côrtes e Leonardo Martins Wykrota

CONSILIÊNCIA E A POSSIBILIDADE DO NEURODIREITO: DA DESCONFIANÇA À RECONCILIAÇÃO DISCIPLINAR.....

Thaís de Bessa Gontijo de Oliveira e Renato César Cardoso

MODELOS DE MORALIDADE

Molly J. Crockett

A INFELIZ BUSCA POR FELICIDADE No DiREITo

Úrsula Simões da Costa Cunha Vasconcellost, Noel Struchiner e Ivar Hannikainen

Além da liberdade: PersPeCtivas Em Nietzsche.

Lucas Costa de Oliveira

A mediaÇão de CONFlitos SOb a PERSPECTIVA do DESENVOLVIMENTO HUMANO: AS CONTRIBUIÇÕES DA PSICOLOGIA POSITIVA

Simone de Biazzi Ávila Batista da Silveira e Deise Brião Ferraz

Neuroimagiologia e aValiação de ResPonsabilidade

Nicole A. Vincent 
ANÁLISE CRÍTICA DA ORIENTAÇÃO DE CIDADÃOS COMO MÉTODO PARA OTIMIZAR DECISÕES PÚBLICAS POR MEIO DA TÉCNICA NUDGE.

Luciana Cristina Souza, Karen Tobias França Ramos e Sônia Carolina Romão Viana Perdigão

Políticas públicas e o deVer de monitoramento: “LEVANdo os Direitos A SÉrio". .252 Ana Paula de Barcellos

Nudges E POLÍticas PÚblicas: uM MECANISMO DE COMBATE AO TRABALHO EM CONDIÇÃo ANÁLOGA À DE ESCRAVO .267

Amanda Carolina Souza Silva, Débhora Renata Nunes Rodrigues e Saul Duarte Tibaldi

REDUZINDO A TRIBUTAÇÃO COGNITIVA: LIÇÕES COMPORTAMENTAIS PARA A DIMINUIÇÃO DOS EFEITOS PSICOLÓGICOS ADVERSOS DA POBREZA.............................................................288 Leandro Novais e Silva, Luiz Felipe Drummond Teixeira, Gabriel Salgueiro Soares e Otávio Augusto Andrade Santos

Políticas PÚBLICAS EM SUICÍDIO: DO PATERNALISMO CLÁSSICO AO PATERNALISMO LIBERTÁRIO E NUDGING

Davi de Paiva Costa Tangerino, Gabriel Cabral e Henrique Olive

Nudges COMO POLÍticA PÚbliCA PARA AUMENTAR O ESCASSO NÚMERO DE DOADORES DE ÓRGÃos PARA TRANSPLANTE

Roberta Marina Cioatto e Adriana de Alencar Gomes Pinheiro

Os PROGRAMAS DE INTEGRIDADE PARA CONTRATAÇÃO COM A ADMINISTRAÇÃO PÚBLICA ESTADUAL: NUDGE OU OBRIGAÇÃo LEGAL? UM OLHAR SOBRE AS DUAS PERSPECTIVAS .386

Cíntia Muniz Rebouças de Alencar Araripe e Raquel Cavalcanti Ramos Machado

Paternalismo libertário e Proteção JURídica do AMbiente: POR QUe PROTEger o AMBIENTE TAMBÉM DEVE SER PROTEGER AS LIBERDADES?

Mariana Carvalho Victor Coelho e Patryck de Araujo Ayala

Políticas PÚblicas baseadas EM EVIdÊNCIAS COMPORTAMENTAIS: REFLEXões A PARTIR do Projeto de Lei 488/2017 do Senado

Pâmela de Rezende Côrtes, André Matos de Almeida Oliveira e Fabiano Teodoro de Rezende Lara

III. ECONOMIA COMPORTAMENTAL: VIESES COGNITIVOS E POLÍTICAS PÚBLICAS .455

ECONOMIA COMPORTAMENTAL E DIREITO: A RACIONALIDADE EM MUDANÇA Marcia Carla Pereira Ribeiro e Victor Hugo Domingues

VIESES COGNITIVOS E DESENHO DE POLÍTICAS PÚBLICAS 
A neurociênCia da moralidade na tomada de DeCisões Jurídicas Complexas e No DESENHO DE POLÍTICAS PÚBLICAS

Erik Navarro Wolkart

Desvio de CARÁter ou SIMPLESMENTE HUMANO? ECONOMIA COMPORTAMENTAL APLICADA AO COMPORTAMENTO DESONESTO

Diana Orghian, Gabriel Cabral, André Pinto e Alessandra Fontana

Políticas Públicas e a ConcretizaÇão de direitos sociais: TOMAdA DE DECisão, ARQUITETURA DE ESCOLHAS E EFETIVIDADE

Ana Elizabeth Neirão Reymão e Ricardo dos Santos Caçapietra

BEHAVIORAL ECONOMICS E DIREITO DO CONSUMIDOR: NOVAS PERSPECTIVAS PARA O ENFRENTAMENTO DO SUPERENDIVIDAMENTO .568

Samir Alves Daura

A EDUCAÇÃo FORMAL PARA O CONSUMO É GARANTIA PARA UMA PRESENÇA REFLETIDA DO CONSUMIDOR NO MERCADO? UMA ANÁLISE COM BASE NA BEHAVIORAL LAW AND ECONOMICS (ECONOMIA COMPORTAMENTAL) 600

Marcia Carla Pereira Ribeiro e Edson Mitsuo Tiujo

LIBET, DETERMINISMO E CONSUMO: AS INFLUÊNCIAS DO MARKETING E A RELEVÂNCIA DA DELIBERAÇÃo CONSCIENTE NA SUPERAÇÃo CONDICIONAL DE HÁBITOS DE CONSUMO PERIGOSOS616 Émilien Vilas Boas Reis e Leonardo Cordeiro de Gusmão

CiÊNCIA DO DIREITO TRIBUTÁRIO, ECONOMIA COMPORTAMENTAL E EXTRAFISCALIDADE. .640 Hugo de Brito Machado Segundo

IV. CoMportamento JUdiCiAL: INFLUÊNCIA DE FATORES EXTRAJURÍDicos .660

FATORES METAPROCESSUAIS E SUAS INFLUÊNCIAS PARA A FORMAÇÃo DA DECISÃo JUDICIAL .662 Rogério Roberto Gonçalves de Abreu, Lúcio Grassi de Gouveia e Virgínia Colares

“A VIDA COMO ELA É": COMPORTAMENTO ESTRATÉGICO NAS CORTES Patrícia Perrone Campos Mello

A COMPOSIÇÃo do ÓRGão COLEGIAdo E SEUS EFEITOS NA TOMADA DE DECISÃo .720 André Garcia Leão Reis Valadares

Das 11 ilhas ao centro do arquipélago: os superpoderes do Presidente do STF DURANTE O RECESSO JUDICIAL E FÉRIAS .741 José Mário Wanderley Gomes Neto e Flávia Danielle Santiago Lima 
RAZÃo, EMOÇÃo E DELIBERAÇÃO: AS ADEQUAÇÕES REgIMENTAIS do SUPERIOR TribUNAL DE JUSTIÇA PARA A FORMAÇÃo DE PRECEDENTES EFICAZES

Peter Panutto e Lana Olivi Chaim

Heurística de ancoragem e fiXaÇÃo de danos morais em JUizados especiais Cíveis no Rio DE JANEIRO: UMA NOVA ANÁLISE 778

Fernando Leal e Leandro Molhano Ribeiro

LA PROTECCIÓN DE LOS DERECHOS POLÍTICOS FRENTE A LAS FUNCIONES DISCIPLINARIAS DE LAS AUTORIDADES ADMINISTRATIVAS: SUBSIDIARIEDAD Y DEFERENCIA EN EL SISTEMA INTERAMERICANO DE DERECHOS HUMANOS Jorge Ernesto Roa Roa

V. A influênCia do gÊNERo no PROCESSO DECisório JUdiCial

Como os Juízes decidem os Casos de estupro? ANALISANDo SENTENÇAS SOb A PERSPECTIVA DE VIESES E ESTEREÓTIPOS DE GÊNERO 826 Gabriela Perissinotto de Almeida e Sérgio Nojiri

GÊNERO E COMPORTAMENTO JUDICIAL NO SUPREMO TRIBUNAL FEDERAL: OS MINISTROS CONFIAM MENOS EM RELATORAS MULHERES?

Juliana Cesario Alvim Gomes, Rafaela Nogueira e Diego Werneck Arguelhes

Hércules, Hermes e a Pequena Sereia: uma reflexão sobre estereótipos de gênero, SUBPRESENTAÇÃo DAS MULHERES NOS TRIBUNAIS E (I)LEGITIMIDADE DEMOCRÁTICA DO PODER JUDICIÁRIO. .878 Jane Reis Gonçalves Pereira e Renan Medeiros de Oliveira

Prisão Cautelar de gestantes: análise do Fundamento filosófico da decisão do Habeas CoRpus N. 143.641 912

Artur César Souza e Giovania Tatibana de Souza

VI. Neurodireito APlicado ao direito E Ao Processo PENAL....................................926

CÉREbros QUe PUNEM: UMA REVISÃo CRÍTICA DA NEURoCIÊNCIA DA PUNIÇÃo .....................928 Ricardo de Lins e Horta

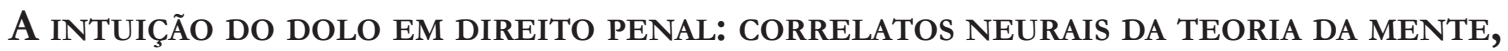
RACIOCÍNIO INDUTIVO E A GARANTIA DA CONVICÇÃO JUSTIFICADA. .946 Thiago Dias de Matos Diniz e Renato César Cardoso

As COMUNIDADES EPISTÊMICAS PENAIS E A PRODUÇÃo LEGISLATIVA EM MATÉRIA CRIMINAL..... 961 Stéphane Enguéléguélé 
DELINQUÊNCIA JUVENIL: RELAÇÕES ENTRE DESENVOLVIMENTO, FUNÇÕES EXECUTIVAS E COMPORTAMENTO SOCIAL NA ADOLESCÊNCIA .

André Vilela Komatsu, Rafaelle CS Costa e Marina Rezende Bazon

Límites TEMPORALES A LAS PENAS PRIVATIVAS DE LIBERTAD ATENDIENDO AL DESARROLLO PSICOSOCIAL.

Silvio Cuneo Nash

NEURolaw E AS PERSPECTIVAS PARA UMA ANÁLISE OBJETIVA DO COMPORTAMENTO SUGESTIONADO: REPERCUSSÃO DAS FALSAS MEMÓRIAS NA ESFERA PENAL

Mariana Dionísio de Andrade, Marina Andrade Cartaxo e Rafael Gonçalves Mota

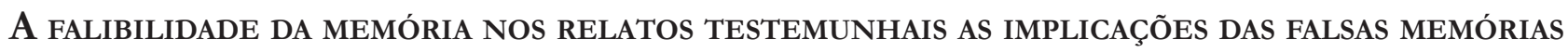
NO CONTEXTO DOS CRIMES CONTRA A DIGNIDADE SEXUAL

Caroline Navas Viana

A (IR)REPETIBILIDADE dA PROVA PENAL DEPENDENTE DA MEMÓRIA: UMA DisCUSSÃo COM BASE NA PSICOLOGIA DO TESTEMUNHO. 1058

William Weber Cecconello, Gustavo Noronha de Avila e Lilian Milnitsky Stein 


\section{Fatores metaprocessuais e suas influências para a formação da decisão judicial*}

* Recebido em 02/05/2018

Aprovado em 24/05/2018

** Doutorando em Direito, Processo e Cidadania pela Universidade Católica de Pernambuco (UNICAP/PE). Mestre em Direito Econômico pela Universidade Federal da Paraíba (UFPB). Professor do Centro Universitário de João Pessoa (UNIPÊ/PB). Juiz federal em João Pessoa/PB. Email: rogerioroberto@hotmail.com.

*** Professor Adjunto III da Universidade Católica de Pernambuco, onde é pesquisador e leciona nos cursos de graduação, especialização, Mestrado e Doutorado em Direito. Possui graduação em Ciências Jurídicas pela Universidade Federal de Pernambuco (1989), Mestrado em Direito pela Universidade Federal de Pernambuco (1994) e Doutorado em Ciências Jurídicas pela Universidade de Lisboa (2002). Atua nas áreas de Direito Processual Civil e Hermenêutica Jurídica, Membro do grupo de pesquisa LOGOS - Processo, Linguagem e Tecnologia. Parecerista em diversos periódicos jurídicos, dentre outros: RBDPRO, Revista Eletrônica de Direito Processual, Revista do Centro de Estudos Judiciários da Justiça Federal e Revista da Esmape. Coordenador de Publicações da ENFAM/STJ. Conselheiro Fiscal da ABDPRO (Associação Brasileira de Direito Processual). Secretário Adjunto do IBDP (Instituto Brasileiro de Direito Processual). Membro da ANNEP (Associação Norte-Nordeste de Professores de Processo). Já exerceu o magistério na condição de professor visitante em diversas pós-graduações brasileiras. Autor de diversas publicações jurídicas. Juiz de Direito em Recife-PE. Email: luciograssi13@gmail.com.

**** Mestrado (1992) e Doutorado (1999) em Linguística pela Universidade Federal de Pernambuco (UFPE). Realizou estágio pósdoutoral em Direito, na Universidade de Brasília, em 2011. Atualmente, é professora, adjunta IV, da Universidade Católica de Pernambuco (UNICAP), atuando na graduação, mestrado e doutorado em Direito. Tem experiência na área de Linguística Aplicada ao Direito, atua na linha de pesquisa da Análise Crítica do Discurso Jurídico, construída no âmbito do PPGD-UNICAP. Ministra disciplinas relativas à linguagem jurídica em diversas escolas de magistratura no país. Fundadora da Associação de Linguagem e Direito (ALIDI - www.alidi.com.br) criada no âmbito do Grupo de Pesquisa Linguagem e Direito (Plataforma Lattes $\mathrm{CNPq}$ ), do qual é líder. Integra o Grupo de pesquisa Logos: processo, linguagens e tecnologias (Plataforma Lattes CNPq).Email: virginia.colares@gmail.com.

\section{Metaprocessual factors and its influence on the judicial decision-making process}

\author{
Rogério Roberto Gonçalves de Abreu** \\ Lúcio Grassi de Gouveia*** \\ Virgínia Colares****
}

\section{Resumo}

Nosso objetivo, no presente trabalho, está em examinar, brevemente, a influência que influxos alheios aos fatos, às provas e ao direito - aqui chamados de fatores metaprocessuais da decisão — podem produzir no processo de tomada de decisão judicial. Para tanto, partimos do exame das ideias freudiana e junguiana sobre o inconsciente, especialmente acerca de sua existência no dispositivo psíquico humano e do papel que desempenha para a formação dos estímulos produtores de ações e decisões. Na sequência, examinamos a noção de neutralidade do juiz em cotejo com a abordagem sobre o inconsciente freudiano, concluindo por sua inexistência como fato no mundo e pelo reconhecimento de sua natureza mítica. Posteriormente, analisamos, como fatores metaprocessuais de significativa relevância, as tendências implícitas, a idade e os valores religiosos do julgador com base nos trabalhos de pesquisadores que investigaram, empiricamente, o papel de tais influxos para o processo de tomada de decisão judicial em determinadas espécies de demandas. Ao final do trabalho, sustentamos que os achados empíricos examinados nos permitem concluir pela verificação de uma forte associação entre os fatores metaprocessuais analisados e os resultados de decisões judiciais. Acreditamos que o trabalho possa colaborar para melhor compreensão do processo de formação da decisão judicial, dada a escassez de textos especificamente sobre o tema.

Palavras-chave: Processo de tomada de decisão judicial. Fatores metaprocessuais. Influência.

\section{Abstract}

In the Brazilian justice system, the judicial decision-making process must comprehend the facts, the evidences and the law related to the case under judgment. Accordingly, judges are forbidden to take into account elements not related to these inputs, lest their decisions are completely void and unable to produce any effect. Nonetheless, in real life, we can find external inputs playing an important role in judicial decision-making process, what has made us to conduct a brief study on the matter. We start from the examen of some freudian and junguian writings on the unconscious, specially 
about its existence in the human psychic device and the possible role it plays at the genesis of the stimulus as to which actions and decisions are grounded. Afterwards, we examine the notion of judicial neutrality according to the freudian unconscious approach, so as to conclude for its non-existence as a fact in the world and for the acknowledgement of its mythical nature. In the next step, we analyze, as such remarkable types of external inputs, the implicit biases, the age and the religious values of the judges, taking into account a few works whereby researchers have published their findings on the influence of such inputs to the judicial decision-making process in certain instances of claims. In the end, we support the idea according to which the empirical findings allow us to verify a strong association between the before mentioned external factors and the outcomes of the judicial decision-making process. Whereas the scant literature about the issue in Brazil, we believe we can collaborate to a better comprehension on the judicial decision-making process.

Keywords: Judicial decision-making process. Metaprocess factors. Influence.

\section{INTRODUÇÃO}

A função jurisdicional se define como aquela, entre as funções do poder do Estado, responsável pela resolução dos conflitos por meio da elucidação dos fatos e da aplicação do ordenamento jurídico na justa composição da lide. Escrevendo sobre Teoria Geral do Processo, ensinam os clássicos que o exercício da jurisdição, entre outras finalidades, compreenderia a pacificação social e a garantia da autoridade do Direito ${ }^{1}$, sem prescindir da legitimação das decisões pela participação em contraditório.

No que diz respeito ao Princípio do Contraditório, já não podemos defini-lo como a mera garantia de audição das partes, especialmente daquela contra quem se haja apresentado alguma demanda. A decisão judicial é algo a ser construído pelo trabalho conjunto de todos os sujeitos do processo, que são alçados à condição de iguais para efeito dessa empresa colaborativa, a sentença. O contraditório funcionaria como um combustível devidamente catalisado pelo Princípio da Cooperação ${ }^{2}$, para que a resposta do poder judiciário, mais do que simplesmente correta e justa, seja dotada da necessária legitimidade democrática, requisito de qualquer ato estatal em tempo de paz

A verdadeira participação em contraditório depende da efetiva influência das partes para a construção do conteúdo da decisão, que já não pode ser produto exclusivo do trabalho do juiz. O novo Código de Processo Civil, em sintonia com esse pensamento, proíbe ao julgador decidir com base em fundamento sobre

1 Sobre os escopos do processo civil: DINAMARCO, Cândido Rangel. Instituições de direito processual civil. 4. ed. São Paulo: Malheiros, 2004. v.1. p. 125. DINAMARCO, Cândido Rangel. A instrumentalidade do processo. 5. ed. São Paulo: Malheiros, 1996. p. 149.

2 Considerando que o contraditório funciona a partir do empoderamento das partes para a construção da decisão judicial com o juiz, o princípio da cooperação tem o condão de lhe conferir substância e materialidade. Sob esse viés, a decisão se legitima a partir da efetiva participação de sujeitos processuais (partes e juiz) no processo de sua formação, sujeitos que dialogam e cooperam ativamente na composição do núcleo da prestação judicial. Podemos dizer, pois, que não pode haver contraditório legitimador sem cooperação.

Nessa linha, afirma Lúcio Grassi de Gouveia:

"A presença ativa e participante das partes servirá como forma de controle dos amplos poderes do juiz na tradução jurídica do fato social, limitando o arbítrio, favorecendo o processo dialógico, que é a garantia maior de objetividade e da maior abertura na decisão. A parte passa a ter efetiva possibilidade de atuar sobre o desenvolvimento e sobre o êxito da controvérsias tendo importância não só o resultado a ser obtido mas a forma como o mesmo o será, no que podemos vislumbrar até mesmo uma função A função legitimadora do princípio da cooperação intersubjetiva no processo civil brasileiro legitimadora do princípio da cooperação intersubjetiva no processo civil moderno, inclusive no brasileiro”. GOUVEIA, Lúcio Grassi de. A função legitimadora do princípio da cooperação intersubjetiva no processo civil brasileiro. Revista de Processo, São Paulo, v. 172, p. 32-53, jun. 2009.

3 Sobre a legitimação da jurisdição pelo contraditório e pelo devido processo legal, conferir: DINAMARCO, Cândido Rangel. Instituições de direito processual civil. 4. ed. São Paulo: Malheiros, 2004. v.1. p. 215. Conferir também, do mesmo autor: DINAMARCO, Cândido Rangel. Fundamentos do processo civil moderno. 5. ed. São Paulo: 2002. v. 1. p. 124. Ainda sobre o tema, mas com os olhos no processo penal: LOPES JÚNIOR., Aury. Introdução crítica ao processo penal: fundamentos da instrumentalidade constitucional. 4. ed. Rio de Janeiro: Lumen Juris, 2006. p. 267. 
o qual não tenham tido as partes a oportunidade de se manifestar. Embora seja possível argumentar que, nesse momento, o legislador tinha em mente apenas os fundamentos jurídicos, parece lógico que a norma compreenda, predominantemente, os aspectos fáticos: seria absurdo que o juiz pudesse decidir a demanda com base em juízo sobre fatos ao arrepio de qualquer alegação ou discussão dos sujeitos parciais.

Em vista disso, a decisão judicial deve espelhar com exatidão o que haja ocorrido no curso do processo, levando em conta as afirmações de fato, a produção de provas e as alegações de direito. É a aplicação do antigo brocardo segundo o qual “o que não está nos autos, não está no mundo". Ainda que o resultado da decisão, pela procedência ou improcedência da pretensão, seja uma surpresa para as partes, os elementos de fato e de direito vertidos linguisticamente na sentença como razões de decidir não podem ser estranhos ou desconhecidos a qualquer delas.

Toda essa linha de pensamento fundamenta um princípio básico em matéria de processo e exercício da jurisdição: no que diz respeito às afirmações de fato e aos meios de prova, o juiz somente poderá julgar com base no que for produzido ou discutido pelos sujeitos processuais e regularmente internalizado nos autos. Quanto aos fundamentos jurídicos, poderão as partes apresentar seus argumentos, permitindo-se ao juiz julgar com base em fundamento jurídico diverso, desde que o submeta à discussão das partes (CPC, art. 10). Enfim, tudo que possa ou deva influir no desfecho do processo e no resultado do julgamento deve ser conhecido pelos litigantes, acessível à discussão e passível de reforço, esclarecimento ou oposição.

Para controle de tal imposição, exige-se que o julgador demonstre às partes conhecer os fatos e as provas, o que deverá fazer nos tópicos da identificação e, mais particularmente, do relatório da sentença. Em seguida, terá de revelar linguisticamente o processo mental que o conduziu à decisão por fim adotada, lidando, exclusivamente, com os elementos fáticos já contidos no relatório e com os fundamentos normativos que lhe darão suporte à conclusão. A resolução da lide, apresentada às partes como a resposta do Estado a seu pedido de justiça, deverá surgir ao final do raciocínio do julgador - linguisticamente descrito na sentença - e guardar absoluta coerência com os elementos examinados e confrontados.

Na teoria, pelo menos, é o que deveria ocorrer. A confiança popular na justiça da jurisdição estatal depende da crença nesse hermetismo processual que, supostamente, expurgaria do processo de tomada de decisão tudo que não se considerem fatos, provas e normas ${ }^{5}$, o que seria controlável com base em um exame sobre o relatório e a fundamentação do ato decisório. Parece-nos, contudo, que esse bermetismo não possa eliminar da equação um elemento ainda essencial ao ato de julgar: a natureza invariavelmente humana do julgador.

O juiz é, naturalmente, um ser humano. Expõe-se, desde a infância, a toda sorte de abalos psicológicos e emocionais que lhe caracterizam a história de vida, compondo-o como um sujeito único no mundo, dotado de qualidades e defeitos que lhe influenciarão toda a existência. Ao decidir, o juiz não se despe da condição de ser humano. $\mathrm{O}$ ato de julgar, portanto, é praticado nessa condição: a de quem carrega uma infinidade de caracteres que fazem dele, juiz e ser humano, tudo que ele é ${ }^{6}$. A necessidade desse processo mental — que consiste no raciocínio para chegar à conclusão a partir dos elementos de fato e de direito pertinentes à causa - abre o flanco da função jurisdicional a uma gama de interferências de impossível previsão e controle. Tais interferências podem não aparecer na fundamentação textual do julgado, mas seus reflexos se inserem no processo mental de decidir, ainda que o julgador não saiba. Algumas dessas interferências são estudadas no presente trabalho.

Partindo da premissa de que o ato de julgar é um processo mental e, assim, um produto da mente do

4 Cf. arts. $9^{\circ}$ e 10 do CPC, 2015.

5 Cf:: PAMPLONA FILHO, Rodolfo. O mito da neutralidade do juiz como elemento de seu papel social. Ciência Jurídica, ano. 12, v. 81, p. 32-45, maio/jun. 1998.

6 "O processo decisório poderá consistir em opções valorativas conflitantes em que, diante de algumas decisões possíveis, o aplicador, utilizando-se de sua carga de conhecimentos, ideologia, emoções, personalidade e formação, escolherá a que entender adequada". GOUVEIA, Lúcio Grassi de. A função legitimadora do princípio da cooperação intersubjetiva no processo civil brasileiro. Revista de Processo, São Paulo, v. 172, p. 32-53, jun. 2009. 
julgador ${ }^{7}$, procuramos discutir por que o juiz não conseguiria expurgar de seu trabalho todo e qualquer insumo alheio aos fundamentos fáticos e jurídicos da lide. Daí a proposta de analisar elementos teóricos que fundamentem, tanto quanto possível, a influência do inconsciente sobre os atos humanos conscientes, o que nos levou a um breve exame sobre as ideias freudiana e junguiana acerca dessa intrigante parte do dispositivo psíquico.

Na sequência, procuramos tratar da ideia de neutralidade judicial, buscando demonstrar que os mesmos fatores que moldam o inconsciente humano - compondo-o como uma parte poderosa e influente na formação e produção dos estímulos que se transformam em nossos atos conscientes - estão presentes na visão daqueles que enxergam a natureza mítica da neutralidade do julgador e que, portanto, negam-lhe existência como um fato da vida real.

Por fim, analisamos como estudos empíricos verificaram a conexão entre determinados fatores externos — os quais chamamos aqui de fatores metaprocessuais, em oposição aos fatores (ordinariamente) processuais, quais sejam, os fatos, as provas e as normas (o direito) — e o resultado de decisões judiciais. Nessa parte do trabalho, examinamos publicações sobre pesquisas empíricas que investigaram a influência de determinados influxos sobre o processo de tomada de decisão judicial: as inclinações implícitas, a idade e, finalmente, os valores religiosos do julgador.

\section{O INCONSCIENTE COMO INSUMO NA DECISÃO DITA RACIONAL}

A decisão judicial é um produto do intelecto humano ${ }^{8}$. De fato, não podemos concordar que o juiz, ao decidir, exerça um trabalho puramente mecânico, por mais repetitivas que sejam as sentenças sobre determinados temas, mais facilidades que a adoção do processo judicial eletrônico traga ao serviço forense e, finalmente, por mais reiteradas que sejam as pretensões nos julgamentos das demandas de massa. Julgar é um trabalho intelectual e, portanto, um ato puramente mental'.

Tomando de empréstimo a visão kelseniana que classifica a interpretação jurídica como ato de cognição ou de vontade ${ }^{10}$, poderíamos dizer que, sob determinado ponto de vista, a decisão judicial se apresenta como

7 Sem prejuízo da colaboração das partes no fornecimento dos dados de fato e de direito considerados pelo juízo em seu raciocínio como processo mental. A afirmação de que a decisão é um "produto da mente do julgador" não invalida a afirmação anterior de que a decisão deva ser um produto do trabalho colaborativo dos sujeitos do processo, em sintonia com os princípios do contraditório e da cooperação.

8 No presente trabalho, tratamos da decisão judicial sob um viés individual, não institucional, como o faz José Rodrigo Rodriguez em sua interessante crítica à racionalidade jurídica e judicial no Brasil, na obra Como decidem as cortes?: para uma crítica do direito (brasileiro), publicada pela Editora FGV. Nesse trabalho, Rodriguez examina a fundamentação das decisões judiciais sob o prisma da argumentação e racionalidade, criticando a forma opinativa de decidir individualmente e assistemática de decidir coletivamente. Seu alvo, portanto, não se confunde com o nosso, mas não podemos negar que o autor compartilha conosco da preocupação sobre a gênese do processo de tomada de decisão.

9 É óbvio que o ato de julgar não se confunde com o de redigir a decisão, de assiná-la ou de validá-la no sistema. Esses não seriam atos puramente mentais, a começar da lógica razão de serem condutas, ou seja, ações materialmente externas em relação à mente humana. Atentando sempre para a precisão possível do significado das palavras, encontramos no ato de julgar aquele processo mental por meio do qual um problema é resolvido, uma escolha é feita, uma valoração é formulada. A externalização desse julgamento pelos diversos meios possíveis é outro ato, que não se confunde com o primeiro e que, em verdade, sequer precisa existir. Ao estudarmos o "processo de tomada de decisão", precisamos especificar que a "decisão" a que nos referimos ainda não é o ato processual decisório, mas o processo mental que forma na mente do juiz aquilo que, no futuro, constituirá a essência do primeiro.

10 De acordo com Kelsen, a interpretação jurídica realizada pelo aplicador do direito diferiria daquela realizada pelo cientista. Uma vez que não seria possível chegar, a partir de determinado texto, a uma "única decisão correta", o trabalho interpretativo do cientista se limitaria a conhecer e apontar todas as possibilidades de resultado, não lhe cabendo escolher qualquer delas. Já o aplicador do direito, tendo que resolver o caso concreto e deparando-se com uma pluralidade de soluções, terá que escolher aquela que melhor atenda às peculiares necessidades do caso, motivo por que sua atuação ultrapassaria a simples "cognição" para se tornar um ato de "vontade". Por essa razão, o autor afirma que, "através deste ato de vontade se distingue a interpretação jurídica feita pelo órgão aplicador do Direito de toda e qualquer outra interpretação, especialmente da interpretação levada a cabo pela ciência 
ato de cognição e de vontade. Como ato de cognição, traduz-se no trabalho do juiz em conhecer os fatos, as provas e o direito aplicável para, em seguida, formular o raciocínio que lhe permitirá estabelecer as soluções possíveis para o problema jurídico apresentado pelas partes. Como ato de vontade, consistirá na opção definitivamente realizada entre aquelas possíveis e, simultaneamente, em sua aplicação ao caso, fixando a norma in concreto que o disciplinará, ativando os poderes do Estado para efetivá-la no mundo real. Esse aspecto nos mostra a insuficiência da atividade cognitiva para o propósito da decisão como instrumento da função jurisdicional. Dado que não caberia ao Estado apenas prover soluções em tese, o juiz deve, decidindo a demanda, impor a vontade condicionadora do Estado, capaz de eliminar a dúvida, transformar relações jurídicas e mesmo reconstruir o mundo dos fatos ${ }^{11}$ : tudo quanto seja necessário para a restauração da ordem jurídica.

Tratando a decisão como um produto da mente, poderíamos ceder à tentação de identificá-la como ato puramente racional. É natural acreditar que decisões judiciais, como produtos da razão, sejam atos racionais. Afinal, é mandamento constitucional que os atos decisórios sejam fundamentados, sob pena de invalidade e ilegitimidade democrática ${ }^{12}$. No entanto, pensamos que tal associação compreenda, implicitamente, uma outra, ligada à ideia de que os aspectos cognitivo e volitivo da decisão exigem que o ato de julgar e o produto do julgamento sejam dotados não apenas de coerência interna (estrutural), mas igual e principalmente de coerência externa (conexão com os fatos, as provas e o direito), o que demandaria do julgador pleno contato com a realidade. Em outras palavras, além de racional, a decisão judicial também teria que ser um produto do intelecto consciente do julgador, perfeitamente apto a conhecer e a compreender os dados do mundo exterior que lhe permitirão o cumprimento de seu dever. Por esse prisma, a decisão judicial seria um ato puramente racional e consciente.

Essa compreensão negaria, contudo, a existência de um inconsciente humano atuante e efetivo em relação à prática dos atos racionais. Com base em escritos de Sigmund Freud e Carl Gustav Jung, pensamos que a decisão judicial, como qualquer conduta humana, seja tomada sob o influxo de ideias e percepções conscientes e inconscientes, o que impediria ao juiz purificar o ato de decidir, eliminando totalmente quaisquer fatores externos ou mesmo sua influência no resultado do julgamento. Em sintonia, acreditamos que fatores externos ao processo, alheios aos fatos, provas e fundamentos jurídicos apresentados e discutidos pelos sujeitos processuais, influenciem o ato de julgar e, consequentemente, o resultado dos julgamentos. Tais influências, obviamente, não podem figurar na fundamentação da decisão e, a priori, ainda que discutidas pelas partes, não podem justificar lógica e coerentemente a conclusão do julgador. Sem embargo, cremos que elas tenham um papel significativo como insumos subliminares, infiltrando-se no raciocínio do juiz a partir de seu inconsciente. Daí a necessidade, muito bem sentida por Nereu Giacomolli e Liza Duarte ${ }^{13}$, de examinar, com a necessária atenção, os referidos escritos de Freud e Jung.

jurídica”. KELSEN, Hans. Teoria pura do direito. Trad. João Baptista Machado. 7. ed. São Paulo: M. Fontes, 2006. p. 394.

11 Utilizamos a expressão "vontade condicionadora do Estado" como forma de sintetizar as possíveis decisões judiciais segundo seu efeito em face da realidade. Sob esse viés, a atuação do Estado é condicionadora da realidade porque se presta a influir efetivamente no mundo, imprimindo-lhe a situação fática que esteja em conformidade com o direito. Se há dúvida acerca da existência ou da validade de uma relação jurídica, caberá ao Estado expurgá-la (sentença declaratória); em se verificando a ocorrência de fatos que, segundo o ordenamento jurídico, imponham o surgimento, a modificação ou a extinção de uma relação jurídica, caberá ao Estado transformar os vínculos jurídicos individuais para adaptá-los ao que prescreve o direito (sentença constitutiva); finalmente, em se constatando a ocorrência de fatos que, segundo o ordenamento jurídico, imponham a existência de determinada situação de fato, caberá ao Estado operar essa transformação (sentenças condenatória, mandamental, executiva).

12 Cândido Rangel Dinamarco destaca que a exigência de motivação das decisões judiciais está ligada ao pressuposto político da necessidade de controle das atividades do juiz, sem a qual ficariam abertas as portas ao arbítrio. Ao fundamentar, o juiz presta contas de sua atuação às partes do processo, aos órgãos superiores da magistratura e à própria sociedade. Por fim, o autor destaca que essa fundamentação deve ser coerente e completa, conferindo ao leitor a sensação de que a conclusão ali exposta tenha sido o resultado da apreciação do julgador sobre os elementos de fato e de direito constantes dos autos, sem omitir quaisquer pontos que possam influir e, até mesmo, modificar o resultado do julgamento. DINAMARCO, Cândido Rangel. Instituiçôes de direito processual civil. 4. ed. São Paulo: Malheiros, 2004. v.1. p. 242-243.

13 GIACOMOLLI, Nereu José; DUARTE, Liza Bastos. O mito da neutralidade na motivação das decisões judiciais: aspectos epistemológicos. Revista da AJURIS, v. 33, n. 102, jun./2006. 


\subsection{O inconsciente freudiano: um marco teórico}

De acordo com Freud $^{14}$, a diferenciação do psíquico em consciente e inconsciente é a premissa básica da psicanálise. Ele destaca que o consciente não é a essência, mas uma qualidade do psíquico, que poderá estar ao lado de outras qualidades ou sequer estar presente. Desde o início de sua exposição, mais do que simplesmente afirmar a existência do inconsciente, o autor se atribui a tarefa de desconstruir uma suposta proeminência da consciência nas expressões da vida humana. Para ele, o estado de consciência seria efêmero e passageiro. Um elemento psíquico (uma ideia, um pensamento) se tornaria consciente num instante e inconsciente em outro, sempre podendo voltar à consciência. Nesse intervalo, as ideias são inconscientes, mas apresentam-se em um tal estado de latência que sua iminente passagem à consciência sugeriria um estado de pré-consciência, alcançando tais ideias facilmente o estado de consciência.

No pensamento freudiano, a consciência não resume o alcance da mente humana. O universo do psiquismo não se limitaria ao que é consciente, pois as ideias e pensamentos que deixam o âmbito da consciência não simplesmente desaparecem, mas, ao contrário, mantêm-se no dispositivo psíquico em forma inconsciente. A afirmação de que o estado de consciência sobre determinado pensamento seria passageiro e efêmero sugere que a mente humana seja um imenso repositório inconsciente, cujo conteúdo pode atingir a consciência, mas, apenas, de forma muito limitada, resumida e, assim mesmo, provisória.

Essa linha é desenvolvida pelo autor sob um viés descritivo, em contraste com a abordagem dinâmica que apresenta na sequência, basicamente uma resposta às objeções de cientistas e filósofos de que não haveria elementos inconscientes no dispositivo psíquico. Não obstante seu raciocínio já aponte a existência do inconsciente, Freud avança por outra frente. Segundo o autor, os estudos e pesquisas psicanalíticas sugerem a existência de

poderosos processos ou ideias psíquicas [...] que podem ter, na vida psíquica, todos os efeitos que têm as demais ideias, incluindo efeitos tais que, por sua vez, podem tornar-se conscientes como ideias, embora eles mesmos não se tornem conscientes ${ }^{15}$.

Em termos mais simples, podemos dizer que essas ideias e pensamentos (os "poderosos processos ou ideias psíquicas”) são capazes de produzir efeitos totalmente acessíveis à percepção e sobre os quais o indivíduo pode se tornar perfeitamente consciente - ainda que não tenha, em absoluto, a menor consciência ou percepção sobre a existência das ideias e pensamentos que lhe causariam tais efeitos.

Não deixa de ser fácil ilustrar essa afirmação. Não raramente, pessoas são acometidas de verdadeiras fobias que se lhes apresentam como inexplicáveis à primeira vista. Se o receio de cair e se lesionar pode explicar, em certa medida, o medo de altura, o que explicaria o medo de palhaços, de lugares abertos ou fechados, de multidões, entre outros? Em tais situações e na exata linha do pensamento freudiano, apontaríamos para a existência de ideias contidas no dispositivo psíquico sobre as quais o sujeito não tem consciência, mas cujos efeitos ele sente e percebe, a exemplo dos medos e fobias que o assolam aparentemente sem causa, motivo ou explicação.

Ocorre que tais ideias inconscientes permaneceriam nesse estado de inconsciência porque uma força lhes impediria a passagem à consciência. Caso contrário, explica Freud que tais ideias passariam à consciência e seria fácil perceber que, em muito pouco, difeririam das ideias conscientes. Ele sustenta a irrefutabilidade da teoria, afirmando que teriam sido encontrados, a partir da técnica psicanalítica, meios com os quais seria

14 O exame das ideias de Freud acerca da existência e do papel do inconsciente no dispositivo psíquico humano, para os fins do presente trabalho, concentrou-se no texto intitulado "O Eu e o Id", de 1923, a partir da edição para kindle, da Amazon, das obras completas do autor, de modo que as remissões, salvo anotação diversa, se referem a esse texto. Como se trata de uma tradução do idioma alemão para o português, adotamos as mesmas escolhas vocabulares do tradutor para facilitar as remissões. FREUD, Sigmund. Frend 1923-1925 o en e o id, autobiografia e outros textos: obras completas. São Paulo: Companhia das Letras, 2011. v. 16.

15 FREUD, Sigmund. Freud 1923-1925 o en e o id, autobiografia e outros textos: obras completas. São Paulo: Companhia das Letras, 2011. v. 16. p. 123-133. 
possível cancelar a força opositora e tornar conscientes as ideias em questão. Ao estado em que, por efeito daquela força contrária, as ideias se mantêm enclausuradas no inconsciente, deu o nome de repressão; à força que manteve a repressão, deu o nome de resistência. A psicanálise, portanto, teria o objetivo de anular essa força e afastar a resistência oposta ao afloramento consciente das ideias e pensamentos inconscientes que produzem efeitos sobre a vida consciente do indivíduo. Com a análise, o sujeito adquiriria consciência dessas ideias, o que lhe permitiria lidar com as causas dos efeitos até aquele momento percebidos, mas para os quais simplesmente não tinha explicação.

Freud confirma, assim, que seu conceito de inconsciente parte da Teoria da Repressão. Explica que haveria dois tipos de inconsciente: o primeiro, descrito como um estágio de latente e iminente consciência, seria chamado de pré-consciente; o segundo, denominado simplesmente de inconsciente, seria composto pelas ideias que não podem se tornar conscientes por efeito da força de resistência (i.e., as ideias reprimidas ou, simplesmente, o reprimido). Até esse ponto, conclui pela existência de três conceitos com os quais se deve trabalhar: o de consciente, o de pré-consciente (mais próximo do consciente) e o de inconsciente (dinamicamente reprimido e que não pode facilmente tornar-se consciente), destacando, ainda, que, sob o aspecto descritivo, os dois últimos seriam inconscientes; sob o aspecto dinâmico, apenas o último.

Em relação a esse ponto, o próprio Freud afirma que a diferenciação acima formulada não seria suficiente para explicar a configuração do dispositivo psíquico e resolver os problemas decorrentes de seus estudos psicanalíticos. Ele afirma a existência de diversas outras distinções, com destaque para uma em particular, cuja formulação inclui a função da percepção e apresenta os conceitos de Eu, Ide Super Eu (ou Ideal do Eu) ${ }^{16}$.

No pensamento freudiano, o Eu seria a "organização coerente dos processos psíquicos" de um indivíduo, a que se ligaria a própria consciência. Também no Eu se originaria a repressão, responsável por eliminar do consciente (ou melhor, manter no inconsciente reprimido) determinadas tendências psíquicas. Como não existe consciência sobre essa resistência, Freud conclui pela constatação de um elemento inconsciente no próprio $\mathrm{Eu}$, que se comporta como o inconsciente reprimido, produzindo efeitos sobre o indivíduo sem se tornar consciente. A um só tempo, o Eu concentraria as funções de perceber os influxos externos e internos, organizar os pensamentos conscientes e barrar o acesso do reprimido à consciência.

Dessa forma, caberia à psicanálise a tarefa de abolir as resistências opostas pelo Eu em lidar com as ideias reprimidas. Freud relata que, durante a análise, pacientes teriam experimentado dificuldades ao serem submetidos a determinadas tarefas, falhando em suas associações ${ }^{17}$ quando instados a se aproximarem do reprimido. Acrescenta que, nesses casos, ainda que não o soubessem e mesmo se o percebessem apenas a partir da sensação de desprazer por eles sentida, tais pacientes estariam sob o domínio de uma resistência originária no $\mathrm{Eu}^{18}$.

Em suma, a partir de uma compreensão estrutural, seriam três, não duas, as modalidades de inconscien-

16 Conquanto Giacomolli e Duarte tenham se estendido ao exame do Id e do Super Eu, pensamos que nenhuma contribuição trouxeram com isso para o estudo que realizaram sobre a natureza mítica da neutralidade judicial. Por tal motivo, preferimos aprofundar o exame do inconsciente freudiano no âmbito do Eu para, em seguida, harmonizá-lo com as ideias junguianas. GIACOMOLLI, Nereu José; DUARTE, Liza Bastos. O mito da neutralidade na motivação das decisões judiciais: aspectos epistemológicos. Revista da AJURIS, v. 33, n. 102, jun. 2006.

17 Não apenas Freud, mas também JUNG tratou do teste de associações. Nesse particular, disseram Giacomolli e Duarte: “Convém aqui lembrar Jung, que, através do chamado teste de associações, procurou demonstrar a existência de um inconsciente pulsante e interativo. Com o teste das associações, Jung consegue comprovar a existência de uma atividade inconsciente. As palavras-estímulo que apresentavam um tempo maior de reação em seus experimentos eram por ele consideradas como a expressão da atividade de complexos inconscientes. O complexo inconsciente é definido pelo autor como a imagem de uma determinada situação psíquica de forte carga emocional e, além disso, incompatível com as disposições ou atitudes habituais da consciência". GIACOMOLLI, Nereu José; DUARTE, Liza Bastos. O mito da neutralidade na motivação das decisões judiciais: aspectos epistemológicos. Revista da AJURIS, v. 33, n. 102, jun. 2006.

18 É particularmente interessante o relato das falhas nas associações dos pacientes, das dificuldades no cumprimento de determinadas tarefas e, principalmente, da sensação de desprazer como indício de aproximação ao reprimido no contexto da análise. A constatação empírica sugere a exatidão da tese segundo a qual as ideias reprimidas, apesar de inconscientes, produzem efeitos que interferem no mundo consciente do indivíduo, efeitos absolutamente perceptíveis em intensidade variada, com potencial para influenciar pensamentos, ideias, condutas, decisões. Esse ponto será retomado adiante. 
te: o inconsciente latente, chamado de pré-consciente; o inconsciente reprimido pelo Eu; e um terceiro, existente no Eu e responsável pela repressão que mantém o reprimido fora da consciência. Todos os três atuariam simultaneamente no dispositivo psíquico do ser humano, participando ativamente da composição de cada estímulo que se converteria naquelas atitudes humanas que chamamos de racionais - ainda que, no dia a dia, não tenhamos a menor ideia disso.

\subsection{A colaboração de Jung}

Discípulo de Freud, Carl Gustav Jung trabalhou a temática do inconsciente. Na obra intitulada "Man and his simbols"19, apesar de concentrar seu foco no papel dos sonhos para a psicanálise e no poder da mente humana para criar os símbolos que exsurgem de seu inconsciente, sua abordagem se aproxima, em diversos pontos, daquela de seu mentor. Na verdade, parece combater na mesma frente contra aqueles que se contrapõem à tese da existência do inconsciente no dispositivo psíquico humano, postura que explica nossa escolha em relação à obra e ao autor como objeto de análise para a formação do marco teórico no presente trabalho.

Jung inicia a construção de seu argumento afirmando a absoluta impossibilidade de o homem apreender e compreender completamente os estímulos que lhe chegam aos sentidos. A capacidade de percepção dos influxos provenientes do mundo exterior seria limitada, como limitados são os órgãos dos sentidos. Por mais que determinados instrumentos possam ajudar na recepção de sons e imagens, nossa aptidão para a captação dos estímulos externos, em determinado momento, chega a um limite além do qual o conhecimento e a percepção consciente não conseguem ir.

Segundo o pensamento junguiano, chegando aos sentidos, os estímulos do mundo exterior são internalizados, conduzidos ao aparelho mental e, nesse ambiente, transformam-se em eventos psíquicos internos, tornando-se por isso incompreensíveis e incognoscíveis ${ }^{20}$. Dessa forma, cada experiência do homem compreenderia uma imensa quantidade de aspectos desconhecidos, de maneira que, paradoxalmente, a capacidade humana de percepção e internalização dos influxos externos teria limites que vão além do que é considerado consciente. Em outras palavras, se, por um lado, a percepção humana seria limitada pelas deficiências e fragilidades dos órgãos dos sentidos, por outro, não se limitaria aos processos de captação exclusivamente conscientes.

Em razão disso, Jung afirma que o ser humano percebe inconscientemente uma pluralidade indefinida de estímulos externos e, internalizando-os, transforma-os, também inconscientemente, em eventos e processos psíquicos. Tais eventos psíquicos internalizados, ainda que ignorados pelo sujeito, ressurgem, posteriormente, para produzir-lhe toda sorte de efeitos. Embora o destaque do autor seja para os sonhos ${ }^{21}$, vê-se em Freud que tais efeitos podem assumir diversas formas, o que autoriza a suposição de que possam figurar emoções, pensamentos, ideias, tendências e sentimentos que formam o complexo universo psicoemocional humano.

Temos, portanto, que as percepções humanas nem sempre são conscientes. Os aparelhos sensoriais captam, permanentemente, os estímulos do exterior, que passam pelo processo de internalização, transfor-

19 Precisamente no primeiro capítulo, de sua autoria, que leva o título de "Approaching the Uncounscious".

20 Não sustentamos, com a presente afirmação, um ceticismo científico em qualquer de suas formas. Não é propriamente ao objeto do conhecimento que nos referimos como impossível de compreender, mas a natureza e a forma do próprio evento psíquico em que se transforma o estímulo interno a partir do processo de internalização. Não temos, em suma, como "fotografar" um pensamento, embora possamos ter alguma ideia sobre o que estamos pensando.

21 O autor registra, no entanto, como uma questão de história, a afirmação de ter sido exatamente o estudo dos sonhos que permitiu aos psicólogos estudar os aspectos inconscientes dos eventos psíquicos conscientes, assumindo, assim, a existência do inconsciente, o que seria negado por cientistas e filósofos sob o fundamento de que uma tal assunção implicaria a admissão da existência de duas personalidades no mesmo indivíduo. Se era sua intenção ser irônico, não sabemos, mas o autor, confirmando a suspeita, afirma que essa duplicidade da personalidade era exatamente o que se podia implicar. 
mando-se em eventos psíquicos. Ao contrário do que se pensa, nem sempre o sujeito tem consciência dessa assimilação. Se tais percepções ocorrem de forma inconsciente, isso pode decorrer de várias causas, como falta de atenção, sutileza do estímulo etc. ${ }^{22}$ Malgrado tudo isso, uma vez que tais influxos são internalizados, tornam-se aptos a produzir efeitos como qualquer outro evento psíquico, compondo o acervo inconsciente que poderá ou não ser levado ao consciente, integrando o conjunto de fatores responsáveis pelo comportamento humano.

O inconsciente é, assim, o repositório de pensamentos, ideias e sentimentos que atuam subliminarmente, influindo nas ações e omissões do sujeito sem que ele, necessariamente, o perceba. Esse repositório é formado por tudo quanto haja sido internalizado ou produzido pela mente humana, durante toda a vida do indivíduo. Trata-se de sua história de vida, seus traumas, paixões, medos, frustrações etc. Por mais que sejamos tentados a acreditar na racionalidade das decisões humanas, esse complexo de fatores que permeia o inconsciente compõe o dispositivo psíquico do ser humano, de forma que o produto racional do indivíduo acaba necessariamente tributário, em sua maior parte, do que está abaixo da linha da consciência, a que não se pode negar, ordinariamente, o adjetivo racional. Em vista disso, parece inevitável concluir que os atos ditos racionais jamais são puramente conscientes, sofrendo a intensa influência do que está no vasto e desconhecido acervo inconsciente, que participa decisivamente da construção mental de cada uma das ações e reações humanas. ${ }^{23}$

Não é difícil, no cotidiano, observar sinais do inconsciente humano. Jung chama a atenção para aquelas situações, mais do que frequentes, em que o indivíduo, em determinado momento, não se lembra do que estava para dizer, ou que, apresentando um amigo, esquece seu nome no exato instante em que o diria. É comum imaginar-se que o pensamento haja simplesmente sumido. Explica o mesmo autor que, nessas situações, esses pensamentos não desaparecem da mente do sujeito, tornando-se apenas inconscientes. Conquanto temporariamente em estado de inconsciência, estão prontos para retornar à consciência quando devidamente ativados.

Daí a visão de que pelo menos parte do inconsciente compreenda uma variedade de pensamentos, impressões e imagens temporariamente obscuros, mas que, longe de estarem perdidos, continuam no inconsciente a influenciar a mente do indivíduo. Jung ilustra essa ideia, descrevendo o comportamento do sujeito que se desloca a um cômodo da casa para pegar alguma coisa e esquece o que queria ao chegar. Perplexo, ele hesita, mexe em objetos como se estivesse sonâmbulo, totalmente alheio em relação à busca. Repentinamente, ele se lembra. Embora lhe pareça ter recuperado a memória perdida, a verdade é que jamais a perdera: estava o tempo todo em seu inconsciente, obscurecida, mas, ainda assim, pronta para ser restaurada e focalizada pelo dispositivo consciente.

Essa proposição de que os pensamentos e ideias esquecidos não desaparecem da mente, mas ali permanecem no inconsciente, converge com a ideia freudiana sobre o estado de latência consciente que refere como característico do âmbito pré-consciente, permeado de eventos psíquicos prontos a retornar à consciência tão logo demandados. Jung destaca que isso aconteceria porque o consciente dirigiria a luz de sua atenção a outras ideias, deixando no escuro inconsciente aquelas anteriormente iluminadas. Mais uma vez,

22 Como ilustração, o autor relata a história de um professor que, imerso em uma interessante conversa com um aluno enquanto caminhavam por um lugarejo na zona rural, sente-se repentinamente interrompido por um abrupto fluxo de memórias de sua longínqua infância, sem que pudesse perceber de onde proviria, dado que nenhum dos pontos da conversa se referiria a isso. Sugeriu ao aluno que fizessem a caminhada de volta e, enquanto caminhavam, percebeu o odor de gansos, tendo assim descoberto o influxo de que haviam decorrido as recordações de sua mocidade: ele havia sido criado em uma fazenda onde se criavam gansos. Explica, finalmente, que o odor não gerou, na ocasião, uma percepção suficientemente forte para desviar-lhe a atenção, mas isso não o impediu de agir subliminarmente, fazer exsurgir suas remotas lembranças.

23 "Falo aqui sobre coisas que, conscientemente, vimos ou ouvimos e, subsequentemente, esquecemos. Mas todos nós vemos, ouvimos, cheiramos e provamos muitas coisas sem percebê-las no momento, seja porque nossa atenção está desviada ou mesmo porque o estímulo aos nossos sentidos é muito sutil para deixar uma impressão consciente. O inconsciente, contudo, terá tomado nota deles, e tais percepções sensoriais subliminares representam uma parte significante de nossa vida cotidiana. Sem que o percebamos, elas influenciam no modo como reagimos aos eventos e pessoas" JUNG, Carl Gustav. Man and his symbols. Random House Publishing Group, 2012. p. 414-418. (Tradução Nossa). 
está em sintonia com o pensamento freudiano segundo o qual o que é consciente apenas permanece nesse estado por pouco tempo, isto é, pelo tempo que durar a atenção consciente, antes de o foco se concentrar no objeto seguinte.

Para concluir, retomamos, brevemente, a afirmação segundo a qual as ideias em estado consciente não seriam tão precisas quanto se acredita, que seu significado racional e emocional se revelaria tanto mais impreciso quanto mais atentamente fossem examinadas. Jung explica que, na verdade, toda percepção, todas as experiências, inclusive as que são mantidas no aparelho consciente, passariam ao estado inconsciente, adquirindo nessa ambiência uma tonalidade (igualmente inconsciente) que, dali em diante, tingirá a ideia sempre que restaurada. Assim, aparece como natural que todas as impressões conscientes sejam permeadas por elementos subliminares do inconsciente, ainda que o sujeito não esteja ciente dessa interferência ou dos efeitos que dela decorram para suas decisões, ideias e sentimentos. Apesar da ignorância, todos seriam em parte moldados pelo que se encontra em seu inconsciente, que aflora e lhes tinge cada uma das expressões da vida consciente e, por que não dizer, racional ${ }^{24}$.

\subsection{A decisão judicial como produto (in)consciente do trabalho do julgador}

Em relação ao que propomos nos tópicos anteriores, a existência do inconsciente como integrante do aparelho psíquico perde a condição de mito para assumir um papel de significativa relevância na explicação do que se refira à própria condição humana. A partir dele — ou, melhor, do que se possa encontrar nele — podemos investigar tendências, inclinações e preconceitos, como também sugerir explicações para determinadas condutas e reações em face de certas condições.

A caracterização do ato de julgar como produto da mente do juiz não poderia prescindir de uma abordagem sobre o aparelho psíquico responsável pelo processo mental em que consiste o raciocínio do julgador. Se, de acordo com o ordenamento jurídico, esse raciocínio deve se ater aos fatores ordinariamente integrantes da atividade de julgar (os fatos, as provas, o direito), o que observamos com base nos ensinamentos de Sigmund Freud e Carl Gustav Jung afasta completamente a viabilidade de um hermetismo processual que seja minimamente capaz de expurgar do processo de tomada de decisão os elementos já existentes no dispositivo psíquico do juiz ${ }^{25}$.

O juiz julga com a mente. No processo interno de julgamento, utiliza um aparelho de configuração única, formatado por influxos absolutamente singulares recebidos durante uma vida inteira, permeado por eventos psíquicos que, no dispositivo mental, adquirem uma tonalidade própria e passam a influir em cada pensamento que aflora ao consciente e em cada conduta a partir dali estimulada. Com a sentença, não poderia ser diferente. Ainda que o juiz não mencione quaisquer fatores estranhos ao processo, que faça o possível para omiti-los ou que sequer tenha noção de sua existência, seu acervo inconsciente participa da formação de seus pensamentos conscientes, de forma que, apesar de sua fundamentação the parecer puramente racional, a decisão frequentemente reflete suas ideias inconscientes ${ }^{26}$.

24 "Talvez seja mais fácil entender esse ponto se percebermos o fato de que as ideias com as quais lidamos em nossa aparentemente disciplinada vida consciente não são, de forma alguma, tão precisas quanto gostamos de acreditar. Ao contrário, seu sentido (e sua significação emocional para nós) se torna tanto mais impreciso quanto mais de perto as examinamos. A razão para isso está em que tudo que ouvimos e experimentamos pode se tornar subliminar — ou seja, pode passar ao inconsciente. E mesmo o que nós retemos em nossa mente consciente e podemos reproduzir à vontade adquire uma tonalidade inconsciente que dará cor à ideia sempre que ela for recuperada. Nossas impressões inconscientes, de fato, rapidamente assumem um elemento de sentido inconsciente que é fisicamente significante para nós, ainda que não estejamos conscientemente alertas sobre a existência desse sentido subliminar ou do modo como estende e confunde o sentido convencional. JUNG, Carl Gustav. Man and his symbols. Random House Publishing Group, 2012. p. 508-515. (Tradução nossa).

25 Sem prejuízo de que tais elementos possam ser ativados por fatores externos em qualquer tempo, esteja o sujeito consciente disso ou não. Como dissemos linhas acima, não raramente o indivíduo desconhece determinados eventos psíquicos de seu inconsciente, mas percebe claramente os efeitos deles decorrentes.

26 Considerando-se que a decisão é, quase sempre, antes o produto da percepção e do livre convencimento do julgador que de 
Todos esses fundamentos poderiam sugerir que juízes decidam sempre com base em seus preconceitos, ou mesmo que as decisões judiciais sejam contaminadas por fatores não estritamente processuais e que, dessa forma, reflitam antes as idiossincrasias do julgador do que a justa solução para o litígío. Em nossa opinião, juízes procuram julgar com base nos fatos e provas, interpretando e aplicando o ordenamento jurídico com justiça e equidade. Por mais que suas inclinações pessoais traduzam simpatia ou antipatia por determinado estereótipo, não se propõem, como regra, a abandonar a busca pelo ideal do justo para satisfação de suas preferências. Em outras palavras, não se trata de uma postura consciente do julgador. Não se trata de má-fé ou prevaricação.

Por outro lado, não podemos negar as dificuldades em explicar certos dados relacionados à atividade judicante. Consideremos aleatoriamente uma determinada comarca com cinco varas criminais não especializadas, que recebam feitos por distribuição. Como explicar um número sensivelmente maior de condenações proferidas por um juiz em relação aos demais, ou mesmo a significativa diferença entre o que mais condenou e o que mais absolveu? Nas sentenças condenatórias, como explicar que alguns juízes, analisando casos com idênticas circunstâncias judiciais ${ }^{27}$, fixem penas-bases tão discrepantes das fixadas por outros julgadores? Em matéria de responsabilidade civil, como explicar que alguns juízes definam indenizações significativamente inferiores ou superiores às de seus colegas com mesma competência, ainda que julgando casos semelhantes? Por que alguns juízes condenam mais, ou em maiores valores, sociedades empresárias do que os entes da administração indireta? Por que conferem indenizações maiores ou menores para certos estereótipos de pessoas (pobre/rico, branco/negro, empresário/empregado, mulher/homem, jovem/idoso)?

Em nossa opinião, considerando substratos fáticos e jurídicos similares e apreciações judiciais tão discrepantes, todos esses questionamentos convergem ao mesmo ponto: o inconsciente, com tudo aquilo que carrega, atua fortemente na formação dos critérios de decisão do julgador e em sua particular forma de enxergar o mundo, o que repercute, inevitavelmente, no processo de tomada de decisão e no resultado de seus julgamentos. Embora racional, a decisão não deixa de ser um ato apenas parcialmente consciente.

\subsection{A neutralidade judicial como mito e o inconsciente do julgador}

A imanente polarização exercida pelo inconsciente sobre o conjunto do dispositivo psíquico humano, fazendo de suas decisões eventos psíquicos nunca inteiramente conscientes, torna, para dizer o mínimo, extremamente duvidosa a possibilidade de se agir com neutralidade em qualquer situação da vida real, seja nos atos mais comuns do cotidiano, seja no desempenho das funções mais relevantes do Estado. Malgrado a multiplicidade semântica do vocábulo, a própria ideia de neutralidade contrasta, à evidência, com a atividade de julgar.

Sobre o tema da neutralidade judicial, trabalhos como os de Rodolfo Pamplona Filho e, posteriormente, de Nereu Giacomolli e Liza Duarte podem ser considerados como significativas contribuições de autores nacionais. Suas linhas de abordagem são diversas, mas ambos convergem para o ponto central do debate que nos interessa: a neutralidade, como fato da vida real, não existe.

Nesses dois trabalhos, seus autores se preocupam em distinguir neutralidade e imparcialidade. Destacam

um processo racional de argumentação, a forma eminentemente opinativa de decidir do juiz brasileiro, denunciada por José Rodrigo Rodriguez em Como decidem as Cortes?. Acentua a importância em se examinar de perto quaisquer influxos que possam conduzir o juiz a julgar em determinado sentido. RODRIGUEZ, José Rodrigo. Como decidem as cortes?: para uma crítica do direito (brasileiro). Rio de Janeiro: FGV, 2013.

27 As circunstâncias judiciais estão previstas no art. 59 do Código Penal e compõem a primeira parte do critério trifásico de fixação da pena, previsto no art. 68. Nos passos seguintes, o juiz analisa as circunstâncias atenuantes e agravantes para, ao final, analisar as causas de redução ou aumento de pena. Como nem sempre esses últimos passos são dados em razão da inexistência de elementos de fato que os imponham, preferimos nos ater às circunstâncias judiciais, que são sempre e em todo caso examinadas para fixação da pena-base. Na ausência de fatos que se enquadrem em alguma das circunstâncias ou condições dos passos seguintes, a pena-base se torna definitiva. 
que a imparcialidade é uma postura a ser adotada pelo julgador, que se caracteriza por uma virtual ou simbólica autocolocação em posição equidistante das partes. Além disso, consiste em garantia de legitimidade do processo como função estatal, instrumento do contraditório e do devido processo legal. O juiz imparcial, em resumo, seria aquele que não assume a condição de parte, não toma partido entre a pretensão e a defesa, garante aos sujeitos processuais idênticas oportunidades de influir no desenvolvimento e na conclusão do processo e, por fim, resolve o conflito com justiça, procurando dar a cada um o que lhe seja de direito.

$\mathrm{Na}$ visão de Pamplona Filho ${ }^{28}$, a verdadeira neutralidade exigiria do sujeito um radical distanciamento em face do objeto, uma completa ausência de escolha, algo que considera impossível por entrar em contradição com a própria atitude de escolher um objeto (como no caso do cientista, que precisa selecionar seu objeto de estudo) ou mesmo de se pretender neutro em face dele. Como não seria materialmente possível ao indivíduo abstrair-se completamente de adotar alguma posição, não haveria uma tal neutralidade como fato no mundo real.

Tratando da figura do "juiz neutro", o mesmo autor insiste na tese de sua inexistência, sustentando que nenhum ser humano conseguiria abstrair totalmente "seus traumas, complexos, paixões e crenças (sejam ideológicas, filosóficas ou espirituais) no desempenho de suas atividades", especialmente porque "a manifestação de sentimentos é um dos aspectos fundamentais que diferencia a própria condição de ente humano em relação ao frio 'raciocínio' das máquinas computadorizadas" ${ }^{29}$. O atributo da neutralidade seria, pois, inconciliável com a lenta e arrastada construção de uma história de vida, com a forja da identidade e da personalidade do indivíduo no fogo das emoções positivas e negativas que o viver carrega em si.

A visão de Giacomolli e Duarte ${ }^{30}$ é convergente com esse pensamento. Para eles, nada impede que o juiz julgue de forma imparcial, mantendo-se equidistante das partes, mas isso não significa que seja neutro. A neutralidade implicaria abstrair-se o juiz de suas vivências pessoais, "seus gostos e desgostos, suas paixões, seu eu, seu modo de ser no mundo", o que seria impossível. Sobre o tema, Almeida, Albrecht e Bagatini afirmam que a neutralidade seria uma característica inexigível de qualquer magistrado, uma vez que, ao decidir, ele "inevitavelmente exporá as convicções formadas ao longo de sua vida, mediante a sedimentação de preconceitos, a observação e o desenvolvimento de seu conhecimento" ${ }^{31}$.

Pensamos que imparcialidade e neutralidade, de fato, sejam conceitos bem diversos ${ }^{32}$. Se a imparcialidade, na linha dos autores acima, pode ser traduzida como uma postura a ser adotada pelo juiz como condição de validade do processo e legitimidade da jurisdição concretamente exercida, a neutralidade, por seu turno, não seria uma postura, mas um atributo ou característica do próprio sujeito, que o qualificaria e distinguiria, e de que não se poderia destacar ou despir. Embora essa distinção — entre imparcialidade como postura e neutralidade como atributo — não tenha sido claramente adotada pelos autores referidos, parece ser exatamente o que desponta de seus argumentos contra a existência da neutralidade: o juiz neutro seria aquele ser que conseguiu se desconectar das condições históricas que lhe moldaram a personalidade e o caráter durante toda a vida, deixando de ser a pessoa que era para se tornar uma não-pessoa. Em suma, a neutralidade não implicaria simplesmente adotar-se uma postura, mas, antes, tornar-se um ser diferente ou, melhor ainda, um não-ser, sem história, sem personalidade, sem identidade.

A tese da neutralidade como mito, contudo, não se sustenta apenas na distinção com a imparcialidade.

28 PAMPLONA FILHO, Rodolfo. O mito da neutralidade do juiz como elemento de seu papel social. Ciência Jurídica, ano. 12, v. 81, p. 32-45, maio/jun. 1998.

29 PAMPLONA FILHO, Rodolfo. O mito da neutralidade do juiz como elemento de seu papel social. Ciência Jurídica, ano. 12, v. 81, p. 32-45, maio/jun. 1998.

30 GIACOMOLLI, Nereu José; DUARTE, Liza Bastos. O mito da neutralidade na motivação das decisões judiciais: aspectos epistemológicos. Revista da AJURIS, v. 33, n. 102, jun. 2006.

31 ALMEIDA, Bruno Rotta; ALBRECHT, Diego Alan Schöfer; BAGATINI, Júlia. O juiz e as motivações no ato de julgar: para além das legais. Revista do Departamento de Ciências Jurídicas e Sociais da UNIJUÍ, Ijuí, ano. 20, n. 35, p. 75-99, jan./jun. 2011.

32 Dinamarco afirma que "imparcialidade não se confunde com neutralidade nem importa um suposto dever de ser ética ou axiologicamente neutro”. DINAMARCO, Cândido Rangel. Instituições de direito processual civil. 4. ed. São Paulo: Malheiros, 2004. v.1. p. 201. 
No caso particular da neutralidade do juiz em sua atividade de julgar, convém retomarmos a base teórica dos itens anteriores para examinarmos o papel do inconsciente na descaracterização do juiz como entidade neutra e, bem assim, da decisão judicial como produto hermético de uma atividade ao mesmo tempo cognitiva, volitiva, racional e consciente do julgador.

A decisão judicial, como produto do ato de julgar, seria trabalhada a partir de influxos formados em dois campos distintos: um de "manipulação consciente" e outro de "determinação inconsciente" 33 . O campo de manipulação consciente compreenderia o juízo do julgador sobre as afirmações de fato, as provas e os fundamentos jurídicos, elementos sobre os quais racionalmente constrói a versão linguística de sua decisão, ou seja, o texto com base em que procura justificar sua conclusão, convencer os destinatários e viabilizar aos tribunais o exercício de eventual atividade de controle e revisão.

O campo de determinação inconsciente é explicado pela influência que o acervo inconsciente exerce no dispositivo psíquico, que é, por sua vez, responsável pelo processo mental por meio de que se constrói a decisão. Considerando que a decisão judicial não deixa de ser produto do raciocínio consciente do julgador, as expressões "manipulação" (consciente) e "determinação" (inconsciente) nos parecem mal colocadas. Melhor, no segundo caso, a denominação de campo de influência inconsciente, afastando-se a ideia de que o inconsciente decida e o consciente apenas formule uma expressão linguística racional para justificar a decisão. Ainda assim, a decisão judicial — não apenas a versão linguística ou textual mas o ato materialmente decisório e seu produto — seria sempre influenciada pelo inconsciente do julgador.

A inexistência do atributo da neutralidade se daria, finalmente, em razão da natureza humana do juiz ${ }^{34}$. Como ser humano, o juiz é exposto, desde o nascimento, aos diversos influxos que lhe construirão o acervo inconsciente, projetando-se em todas as expressões de sua vida consciente. Sua história de vida é marcada por experiências particularmente relevantes para a formação de seu caráter e personalidade, seus conceitos e preconceitos, afinidades e antipatias. O ser humano que se torna é o resultado dessa vivência, não lhe sendo possível desvestir-se da condição humana para investir-se em uma outra, intitulada juiz, sem referência, sem passado, sem história.

As decisões desse juiz bumano, a cuja composição psíquica não se nega a existência de um inconsciente poderoso e atuante, não se limitam àquela motivação baseada em fatos, provas e normas. Como já dito, toda sua estrutura psíquica, integrada por elementos conscientes e inconscientes, atua na percepção dos insumos externos e na formação do raciocínio que orienta a fundamentação e conduz ao resultado do julgamento ${ }^{35}$. É nessa arena que se torna possível buscar respostas para as perguntas anteriormente apresentadas, explicando por que os juízes, no desempenho natural de seu trabalho, revelam determinadas tendências de julgamento, seja condenando mais que absolvendo, seja acolhendo mais que indeferindo certas pretensões, seja, ainda, fixando maiores ou menores indenizações para determinadas tipos de danos.

Nessa linha, Giacomolli e Duarte afirmam que:

Esta influência, quase que imperceptível pelo próprio julgador, é inafastável e difícil de ser constatada por quem apreciará a decisão em grau recursal ou nas instâncias superiores. Os juízos, as frases, as

33 GIACOMOLLI, Nereu José; DUARTE, Liza Bastos. O mito da neutralidade na motivação das decisões judiciais: aspectos epistemológicos. Revista da AJURIS, v. 33, n. 102, jun. 2006.

34 “[...] no ato de julgar está um ser humano que também implode em suas questões existenciais, em seus porquês, em suas emoções, nos sentidos que busca da vida e nas próprias expectativas e intenção do que pretende comunicar na sentença". GIACOMOLLI, Nereu José; DUARTE, Liza Bastos. O mito da neutralidade na motivação das decisões judiciais: aspectos epistemológicos. Revista da AJURIS, v. 33, n. 102, jun. 2006.

35 "Não deveríamos dispensar todo conhecimento que diz de nós mesmos. Não deveríamos deixar de reconhecer que somos cegos às escuras de nosso inconsciente que trabalha paralelamente à consciência racional de nós mesmos e do mundo. Não deveríamos deixar de reconhecer que, mesmo quando dizemos estar atuando de maneira racional, é nosso inconsciente que pauta nossas escolhas, justificadas ponto a ponto sob premissas racionais, mas que no fundo maquiam opções impetuosamente inconscientes". GIACOMOLLI, Nereu José; DUARTE, Liza Bastos. O mito da neutralidade na motivação das decisões judiciais: aspectos epistemológicos. Revista da AJURIS, v. 33, n. 102, jun. 2006. 
palavras, estão assentadas nessas estruturas psíquicas, próprias de cada julgador, de cada ser humano. É a totalidade do ser do juiz que produz e determina a decisão, refletindo-se na própria decisão, nas linhas ou nas entrelinhas. A decisão também é o que é o seu prolator ${ }^{36}$.

Não é fácil encontrar na fundamentação linguística as respostas para nossas perguntas, pela mesma razão que não é tão simples detectar, nessas situações, os motivos que orientaram realmente o julgador. Caso contrário, várias seriam as decisões anulatórias proferidas por tribunais em recursos de apelação, mas não é o que acontece. Daí a advertência acima, de que os vestígios dessas influências são praticamente imperceptíveis àqueles que revisam o mérito em grau recursal e apreciam o texto da sentença em busca de mera conformidade entre os fundamentos e o objeto da decisão.

A despeito disso, as influências estão ali, cristalizadas na decisão judicial, essa última sempre um produto não completamente consciente de seu prolator, mas, ainda assim, totalmente identificado com ele. $\mathrm{Na}$ construção da sentença, aos fatores ordinariamente processuais, juntam-se outros, estranhos aos autos do processo, mas nunca ao dispositivo psíquico do juiz. Esses últimos, os fatores metaprocessuais ou extraprocessuais, podem ser definidos como tudo aquilo que, afora os fatos, as provas e o direito, influem no raciocínio do julgador, no processo de tomada de decisão e, ao final, no resultado do julgamento.

\section{FatORES METAPROCESSUAIS ESPECífICOS E A CONSTATAÇÃo EMPírICA DE SUA INFLUÊNCIA NA TOMADA DE DECISÃO}

Como dissemos acima, se existe o que ainda não possa ser excluído do processo de tomada de decisão judicial, em prol de um hermetismo processual que purifique o julgamento de quaisquer fatores alheios aos fatos, às provas e ao direito, é a natureza humana do juiz e tudo que ela carrega, incluindo seu acervo inconsciente, fator de singular relevância para a formação de sua identidade e composição das mais diversas expressões de sua vida. Se é verdade que, quando julga determinada demanda, o juiz procura compor sua fundamentação com base nos fatores ordinariamente processuais, não menos verdade é que, em "se derramando" no ato de julgar, confere ao julgado seu próprio DNA, imprimindo-lhe os reflexos e marcas de sua história de vida.

Ao tratarmos, no tópico anterior, de fatores metaprocessuais, pretendíamos destacar a existência desses insumos que, não compreendidos nos argumentos de fato e de direito das partes e sequer externados pelo juiz, tomam parte no processo de tomada de decisão e influem no julgamento concretamente realizado. Integram, portanto, o "DNA" da decisão. Apesar da multiplicidade de espécies que tais fatores possam assumir, analisamos, nos limites do presente trabalho, apenas três: as inclinações ou tendências implícitas (implict bias), a idade e os valores religiosos do julgador.

\subsection{Inclinações implícitas do julgador}

No contexto de uma pesquisa sobre fatores metaprocessuais da decisão judicial, as inclinações implícitas se revelam um fator de relevante influência no processo de tomada de decisão. Estudos relatam a condução de experimentos para detecção e identificação dessas tendências, analisando como poderiam atuar no resultado de decisões judiciais em casos particulares. A ideia de implicit bias, fundada na ciência da cognição implícita ${ }^{37}$,

36 GIACOMOLLI, Nereu José; DUARTE, Liza Bastos. O mito da neutralidade na motivação das decisões judiciais: aspectos epistemológicos. Revista da AJURIS, v. 33, n. 102, jun. 2006.

37 Irwin e Real evitam, desde o início, atribuir ao termo "bias" uma conotação pejorativa. Buscam, antes, um significado que traduza um desvio de curso, motivo pelo qual nos pareceu mais apropriado traduzi-lo como inclinação ou tendência, em vez de preconceito. Cf. IRWIN, John F.; REAL Daniel L. Unconscious influences on judicial decision-making: the ilusion of objectivity. McGeorge L. Rev. v. 42, n. 1, 2010-2011. 
sugere que o agente nem sempre tem consciência ou controle sobre os processos de percepção, impressão e valoração que motivam suas decisões. Figura a existência de diversos processos mentais implícitos que atuam para além de seu foco consciente, incluindo memórias, percepções, atitudes e estereótipos alojados do campo inconsciente do dispositivo psíquico. ${ }^{38}$

A título de definição, Irwin e Real afirmam que inclinações implícitas constituem processos mentais inconscientes, baseados em atitudes ou estereótipos implícitos, que tomam parte, quase sempre de maneira imperceptível, nas decisões do cotidiano. Salientam ainda que tais inclinações estão radicadas na mecânica fundamental dos processos de pensamento, em que se aprende, desde a infância, a associar itens que, normalmente, aparecem juntos e a logicamente esperar que coexistam em outras circunstâncias, como trovão e chuva, cabelos brancos e idade avançada etc. Os autores ainda afirmam que inclinações implícitas são atitudes e correlações inconscientes, formadas com base nas experiências de vida do indivíduo e mantidas à espreita sob a superfície do plano consciente. A conturbada relação entre o consciente e o inconsciente é novamente destacada e, embora os autores não o digam, parece clara sua conexão a tudo quanto dissemos, com base em Freud e Jung, sobre o papel do acervo inconsciente no processo racional de tomada de decisão.

Quanto à pesquisa empírica em si, os autores relatam que, em meados da década de 1990, o Professor Tony Greenwald (Universidade de Washington) desenvolveu uma ferramenta experimental — conhecida pelo nome de Implicit Association Test (LAT) ou Teste de Associação Implícita - para estudar inclinações implícitas. O teste consistia em apresentar ao examinando, em uma tela de computador, uma sucessão de palavras ou imagens que deveriam ser associadas aos conceitos de "bom" ou "mau" em curtíssimo espaço de tempo. Os indivíduos precisavam avaliar como "bom" ou "mau” palavras como "amor", "alegria", "dor", "tristeza", e, ao mesmo tempo, deviam valorar, como positivos ou negativos, rostos de pessoas (dependendo da inclinação pesquisada) brancas ou negras, jovens ou idosas, magras ou obesas etc. O teste se propunha a detectar e expor inclinações implícitas pela verificação de mudanças no tempo de reação necessário à associação de determinados conjuntos de palavras e imagens.

De acordo com os resultados, mesmo pessoas que acreditavam não possuir inclinações implícitas contrárias a determinados grupos (raciais, etários ou de gênero), descobriram-se portadoras dessas tendências, uma vez que levaram mais tempo para associar esses grupos a palavras positivas, diversamente do tempo necessário em relação a outros grupos. Em outras palavras, a valoração positiva, nesses casos, levava mais tempo para determinados grupos do que para outros, o que sugeria, pela sutil diferença de tempo e espontaneidade, uma propensão implícita que lhes seria negativa.

Em 1998, juntamente à Professora Mahzarin R. Banaji (Universidade de Harvard) e o Professor Brian Nosek (Universidade de Virginia), o Professor Greenwald disponibilizou o IAT na internet e, com a consequente ampliação de seu alcance, obteve resultados interessantes. A partir dos milhões de testes realizados, eles afirmam ter constatado, em síntese, que:

a) $75 \%$ (setenta e cinco por cento) dos indivíduos demonstraram algum tipo de inclinação implícita em favor dos estereótipos “jovem", "rico" e "branco";

b) a negação pessoal consciente de quaisquer inclinações não lhes afastava a presença (e, acrescentaríamos, a detecção);

c) os membros de grupos minoritários se mostravam menos propensos a demonstrar inclinações por seus grupos do que os membros de grupos majoritários;

d) pessoas que tenham demonstrado inclinações implícitas nos testes IAT seriam mais susceptíveis de se comportar de acordo com essas inclinações nas situações da vida real (face-to-face interactions) em que se aplicariam.

38 Conquanto os autores afirmem, na primeira nota de rodapé de seu texto, a divergência do conceito junguiano de inconsciente com os adotados por autores mais modernos, parece-nos que as ideias de Freud e Jung, retratadas no presente trabalho, estejam em perfeita sintonia com a ideia dos pesquisadores sobre o papel do inconsciente para a noção por eles apresentada sobre implicit bias. 
No tocante a esse último ponto, os autores afirmam que a análise dos dados colhidos com os testes lhes permitiu concluir que o IAT possuiria "validade preditiva", expondo uma significante correlação entre as influências implícitas sugeridas pelos resultados e o comportamento dos sujeitos na vida real. Em outras palavras, a partir da identificação das inclinações e tendências implícitas fundadas no dispositivo psíquico inconsciente do indivíduo, seria possível predizer-lhe um padrão de comportamento em determinadas situações reais. Afirmam, inclusive, que essas inclinações tenderiam a levar o indivíduo a atitudes discriminatórias em face de determinados grupos.

Naquilo que nos interessa mais de perto, colocamos a seguinte questão: de que forma e com que intensidade essas inclinações implícitas apareceriam no contexto do processo de tomada de decisão judicial?

É comum discutir-se, no meio jurídico, se juízes pensam suas decisões da mesma forma que as fundamentam textualmente na sentença. Em outras palavras, questiona-se se o raciocínio real do magistrado seguiria, rigorosamente, o itinerário descrito em seu raciocínio formalmente apresentado na peça decisória. No âmbito forense $^{39}$, muitos afirmam acreditar que os julgadores decidam a causa antes de a conhecer totalmente, tornando pública sua fundamentação apenas para justificar a conclusão já aprioristicamente formulada e cumprir o mandamento constitucional da necessidade de motivação. A academia, de sua parte, não fechou os olhos à questão.

Como reportam os textos de Guthrie, Rachlinski e Wistrich ${ }^{40}$ e de Irwin e Real ${ }^{41}$, estudos anteriores sobre como os juízes chegariam a suas decisões categorizaram duas formas de decidir: uma primeira (modelo formalista), denominada "deliberativa", sugere que a decisão seja o resultado lógico de um raciocínio silogístico, aplicando o juiz a lei aos fatos para obter, de forma racional e ponderada, o resultado; uma segunda (modelo realista), denominada "intuitiva", sugere que o juiz simplesmente decida, ou seja, que chegue ao resultado por meio de processos intuitivos e, posteriormente, se encarregue de construir o raciocínio que explicará deliberativamente a decisão.

A constatação da insuficiência dessas correntes levou Guthrie, Rachlinski e Wistrich a uma nova proposta que, captando traços específicos de ambas, melhor retrataria a realidade do processo de tomada de decisão. Seria o modelo de julgamento intuitive-override. Com fundamento em pesquisas contemporâneas na área de psicologia e em suas próprias observações empíricas, afirmam os autores que, de acordo com o modelo, juízes geralmente decidem segundo processos intuitivos, mas conseguem às vezes anular ou sobrepujar (override) voluntariamente a intuição (processo intuitivo de decisão) por meio da deliberação (processo deliberativo de decisão) ${ }^{42}$.

Nesse ponto, devemos chamar a atenção para um aspecto essencial à compreensão do tema: juízes tomam decisões em situações fundamentalmente diversas. Nos casos em que a decisão deva ser tomada imediatamente, no "calor" da audiência ou sessão em tribunal, o juiz tenderia a um processo de decisão "intuitivo" (blinking). Já nos casos em que a decisão possa ser tomada com ponderação e, por isso mesmo, construída a partir de um raciocínio mais elaborado, o juiz tenderia a um processo decisório "deliberativo" (staring). Daí a hipótese, apresentada por Irwin e Real, de que as inclinações implícitas dos juízes, dada a falta de tempo e oportunidade para uma maior reflexão, possam ser mais influentes nos primeiros (blinking decision-making process) que nos últimos (deliberative decision-making process).

39 Ou seja, fora do âmbito acadêmico e sem qualquer base empírica metodologicamente pesquisada.

40 GUTHRIE, Chris; RACHLINSKI, Jeffrey J.; WISTRICH, Andrew J. Blinking on the bench: how judges decide cases. Cornell Law Faculty Publications, paper 917, 2007.

41 IRWIN, John F.; REAL Daniel L. Unconscious influences on judicial decision-making: the ilusion of objectivity. McGeorge L. Rev. v. 42, n. 1, 2010-2011.

42 "Nosso modelo, em suma, nem enxerga os juízes como os agentes de tomada de decisão puramente dedutivos dos formalistas, nem como como os racionalizadores intuitivos dos primeiros realistas. Antes, enxerga os juízes como pessoas normais que tendem a tomar decisões intuitivas, mas que podem substituir suas reações intuitivas por complexos raciocínios deliberativos. (Tradução nossa). GUTHRIE, Chris; RACHLINSKI, Jeffrey J.; WISTRICH, Andrew J. Blinking on the bench: how judges decide cases. Cornell Law Faculty Publications, paper 917, 2007. 
Ainda sobre esse ponto, afirmam os autores que as inclinações implícitas operariam efeitos de intensidade variável de acordo com o estágio do andamento processual. Nas situações surgidas no curso de um julgamento, o juiz seria chamado a apresentar soluções mais imediatas, prevalecendo a intuição. Nos tribunais de apelação, os juízes seriam mais propensos a decisões deliberadas ao examinarem as postulações, mas atuariam de forma preponderantemente intuitiva em face de requerimentos ou argumentações dirigidas por advogados na sustentação oral, situação que demanda, ordinariamente, uma resposta imediata sob pressão.

As inclinações implícitas se revelam, dessa forma, como uma presença permanente nos juízos e tribunais, participando dos julgamentos e influindo no resultado das decisões. Convencidos disso, os autores afirmam a conveniência de que magistrados se submetam a testes para a identificação de suas eventuais inclinações para melhor conhecê-las, contendo possíveis influências discriminatórias na atividade de julgar. Sugerem, ainda, que os programas de formação de magistrados incluam essa investigação em seus currículos. À guisa de conclusão, parece-nos digno de nota que, a despeito de tudo isso - especialmente do reconhecimento da influência que as inclinações implícitas operam sobre o ato de decidir e o resultado da decisão, como também da conveniência em se adotarem meios para a contenção de interferências indevidas —, os autores reafirmam a crença de que juízes buscam, a todo momento e como regra geral, julgar da maneira mais justa, correta e ética possível ${ }^{43}$.

\subsection{A idade do julgador}

Para tratarmos da idade do julgador como elemento de influência no processo de tomada de decisão judicial, examinamos o estudo conduzido pelos professores Kenneth L. Manning, Bruce A. Caroll e Robert A. Carp, publicado sob o título "Does age matter? Judicial decision making in age discrimination cases" na revista "Social Science Quarterly" (mar./2004). No trabalho em questão, partindo da premissa de que raça e gênero moldariam a visão de juízes no julgamento de casos de discriminação em que esses aspectos estariam em jogo, seus autores procuraram investigar a possível influência que a idade dos julgadores exerceria na composição dos critérios de julgamento do juiz em casos de discriminação ou preconceito etário.

Considerando os resultados de estudos prévios — que constataram a influência de determinados fatores socioeconômicos (como a etnia e o gênero dos juízes) para a orientação de decisões em casos de discriminação especificamente relacionada a tais fatores - os autores hipotetizaram que a idade dos juízes desempenharia um papel importante no processo de tomada de decisão em demandas sobre discriminação etária. Eles esperavam constatar que juízes mais idosos, em comparação com os mais jovens, revelariam maior tendência ao acolhimento de pleitos em demandas por discriminação com base na idade quando apresentados por pessoas igualmente mais idosas ${ }^{44}$.

43 "Juízes naturalmente lutam para chegar a decisões corretas tanto no mérito quanto sob uma perspectiva ética. Inclinações implícitas podem comprometer a capacidade de juízes de chegar a decisões corretas em qualquer dessas perspectivas. O simples reconhecimento da possível influência que inclinações implícitas possam ter na tomada da decisão judicial garante aos juízes mais uma oportunidade de considerar cuidadosamente todos os aspectos da decisão a fim de que possam chegar ao resultado mais correto em ambas as perspectivas. O reconhecimento de inclinações implícitas e da maneira pela qual elas possam impactar a tomada de decisão é o primeiro passo na busca por eliminar quaisquer influências impróprias que elas possam trazer ao processo de tomada de decisão" (Tradução nossa). IRWIN, John F.; REAL Daniel L. Unconscious influences on judicial decision-making: the ilusion of objectivity. McGeorge L. Rev. v. 42, n. 1, 2010-2011. p. 7.

44 "Nossa hipótese é de que juízes mais velhos exibirão um padrão de tomada de decisão mais "pró-demandante" em casos de discriminação etária quando comparados a juízes mais jovens. Essa hipótese é construída a partir de um largo material acadêmico que identificou casos em que atributos sociais como raça ou gênero têm moldado a maneira de ver determinadas questões jurídicas relativas a tais atributos. Por exemplo, Davis, Haire e Songer (1993), Gryski, Main e Dixon (1986) e Allen e Wall (1993) mostraram que juízas são as mais fortemente acolhedoras de demandas promovidas por mulheres em casos de discriminação de gênero. Walker e Barrow (1985) identificaram efeitos de gênero similares na tomada de decisão em cortes distritais, e Songer, Davis e Haire (1994) identificaram um padrão de tomada de decisão diferente para mulheres em casos de discriminação nas relações de trabalho. Outros estudos identificaram influências similares na área racial. Welch, Combs e Gruhl (1988) e Mustard (1998) concluíram que, enquanto juízes brancos tendem a impor penas mais severas a réus afroamericanas do que a réus brancos, juízes afroamericanos tendem a ser mais lenientes em face de réus afroamericanos. Apesar de a literatura nessa área ser pouco conclusiva, estudos sugerem que gênero 
No desenvolvimento do trabalho, eles afirmam ter analisado 544 decisões monocráticas (bench trials) de 287 juízes das cortes distritais federais em casos de discriminação com base na idade, julgados entre 1984 e 1995 em 42 estados americanos, além do Distrito de Columbia e de Puerto Rico. A opção pelas cortes federais distritais teria sido motivada por seu papel como primeira arena em que tais demandas são discutidas, como também por cumprirem uma importante função na elucidação e interpretação dos fatos e na produção das provas. Paralelamente, esses autores teriam examinado 1592 decisões em casos de discriminação racial e de gênero, proferidas no mesmo período e nas mesmas cidades que as decisões mencionadas no parágrafo anterior, examinadas segundo a mesma metodologia.

No tratamento dos dados, a par da minuciosa descrição de sua metodologia de trabalho, dos instrumentos utilizados, do emprego da estatística etc., destacou-se a estratégia em classificar as decisões, segundo a idade de seu respectivo prolator, em três faixas etárias: a primeira, composta pelos magistrados com idade não inferior a 65 anos (idade em que normalmente se aposentam); a segunda, composta por aqueles com idade inferior a 65 e superior a 45 anos; por fim, a terceira faixa, composta pelos juízes com idade não superior a 45 anos (escolhida com base na média de idade no momento do ingresso nas cortes analisadas: 48 anos).

Embora o objetivo declarado dos pesquisadores fosse investigar a conexão entre a idade dos juízes e o resultado de suas decisões em casos de preconceito etário, eles sentiram a necessidade de adotar estratégias para evitar que seus achados fossem questionados como inconclusivos, o que ocorreria se não fossem aptos a refutar explicações alternativas. A constatação, por exemplo, de que juízes idosos acolheriam pleitos fundados em discriminação etária mais frequentemente do que juízes jovens não necessariamente comprovaria a relação entre a idade do julgador e a orientação dos julgados nesse especifico tipo de discriminação, a menos que os dados permitissem excluir uma suposta ligação entre a idade dos juízes e outros tipos de discriminação ${ }^{45}$. Foi exatamente por isso que os pesquisadores empreenderam a coleta e a analise de dados levando em conta também a vinculação político-partidária dos juízes e suas posições no julgamento de casos de discriminação racial e de gênero.

Os resultados obtidos lhes confirmaram a hipótese. Em primeiro lugar, constataram que juízes democratas julgariam mais frequentemente em prol dos demandantes que juízes republicanos nos três casos de discriminação examinados. Constataram, contudo, que a menor diferença percentual (entre julgados pró-requerentes proferidos por juízes democratas e republicanos) foi encontrada, exatamente, nas demandas sobre discriminação etária, significando que a vinculação política exerceria, nos casos de preconceito com base na idade, menos influência do que nas demais formas de discriminação.

Em segundo lugar, constataram que, independentemente da vinculação político-partidária, juízes enquadrados na faixa etária mais idosa (de 65 anos acima) julgariam mais frequentemente em favor dos reclamantes do que os juízes da faixa intermediária (entre 45 e 65 anos). Esses últimos, de sua parte, também julgariam com maior frequência em favor dos reclamantes do que os da faixa mais jovem (até 45 anos). As diferenças seriam muito significativas entre a primeira e a terceira faixas etárias ${ }^{46}$ e se verificariam, inclusive,

e/ou raça podem influenciar perspectivas judiciais em questões jurídicas pertinentes a tais características.” (Tradução nossa). MANNING Kenneth L.; CAROLL Bruce A; CARP, Robert A. Does age matter?: judicial decision making in age discriminations cases. Social Science Quarterly, v. 85, n. 1, mar. 2004. p. 4.

45 Se os pesquisadores analisassem apenas casos de discriminação etária, a constatação de que juízes idosos são estatisticamente mais favoráveis que juízes jovens às demandas por discriminação etária não comprovaria a pretendida vinculação entre idade do juiz e julgamentos favoráveis em discriminação etária. Basta imaginarmos um segundo pesquisador que, analisando eventual vinculação entre a idade do juiz e os resultados de julgamentos em casos de discriminação racial e de gênero, viesse a encontrar percentuais similares ao primeiro, que examinara apenas casos de discriminação etária. A vinculação, portanto, seria caracterizada entre a idade do julgador e qualquer caso de discriminação.

46 "Comparando as faixas dos juízes mais jovens e dos juízes mais velhos, nós identificamos uma razão de probabilidades de 2.66. Isso indica que juízes mais velhos são duas vezes mais propensos que seus colegas mais jovens a proferir um julgamento pródemandante em casos de discriminação etária, sugerindo que a idade seria um influente elemento na formação de decisões em casos fundados na idade." MANNING Kenneth L.; CAROLL Bruce A; CARP, Robert A. Does age matter?: judicial decision making in 
entre juízes com a mesma vinculação política ${ }^{47}$. Esses resultados confirmariam, a priori, que, quanto mais avançada a idade do juiz, maior sua tendência em julgar favoravelmente pretensões sobre discriminação etária, independentemente de sua origem democrata ou republicana.

Esse achado, contudo, ainda comportaria a explicação de que juízes mais idosos poderiam, simplesmente, se tornar mais liberais (mais flexíveis, mais sensíveis, mais "bonzinhos") e, assim, tenderiam a acolher com mais frequência a pretensão em quaisquer casos de discriminação. Com o objetivo de eliminar uma explicação alternativa como essa, os pesquisadores submeteram os dados coletados sobre preconceito racial e de gênero a idêntico tratamento metodológico, enquadrando as decisões nas mesmas faixas etárias que aquelas sobre preconceito etário. Assim, testaram igualmente a influência da idade dos juízes sobre o resultado de seus julgamentos em questões de discriminação com base na raça e no gênero.

A partir do confronto entre os resultados de suas análises, os pesquisadores concluíram que a idade dos juízes não exerceria um papel significativo na definição dos julgados em questões de preconceito racial e de gênero, diferentemente do que ocorreria nos casos de preconceito etário, quando o enquadramento em uma ou outra faixa etária revelou sensíveis diferenças estatísticas na definição dos juízes em prol dos reclamantes ou reclamados. Concluíram, assim, que o avanço da idade dos juízes não os tornava, simplesmente, mais receptivos a quaisquer pleitos sobre discriminação, mas, diversamente, que a idade do julgador tinha um papel proeminente, inclusive com aptidão preditiva, especificamente nos casos de discriminação fundada na idade.

A partir dessas conclusões, os pesquisadores sugerem uma intrigante implicação de suas descobertas: a possibilidade de que juízes venham a, com o passar tempo e à medida que avancem de uma para outra faixa etária, alterar sua postura decisória em questões de preconceito etário. Considerando que aspectos como gênero e raça são invariáveis no tempo, a influência que tais fatores exerceriam sobre o processo de tomada de decisão seria relativamente estável durante a vida do juiz. Já no caso da idade, não se poderia dizer o mesmo. Afinal, juízes envelhecem.

\subsection{Os valores religiosos do julgador}

Entre todos os fatores metaprocessuais de influência na tomada de decisão, um dos mais delicados e, de certa forma, que mais preocupam a sociedade em geral e a comunidade jurídica em particular é aquele ligado aos valores religiosos do julgador, à religião por ele professada, seu sentimento de pertença a determinado grupo ou comunidade religiosa. De maneira semelhante a outros fatores como os vínculos político-partidários e as bases culturais, morais e filosóficas, os valores religiosos podem influir decisivamente nos critérios de julgamento em questões de interesse geral da população. Sua importância, assim, é inquestionável.

Para evitar os percalços naturalmente envolvidos com a ausência de consenso sobre determinadas ideias, devemos fixar alguns conceitos para melhor compreensão. Esse cuidado em estabelecer um sentido mínimo para termos como religião e religiosidade foi adotado por Idleman, que, desde o início de seu trabalho, mostrou-se preocupado com as repercussões que seu alcance poderia trazer. Ele afirma que, quanto mais amplo for o conceito de religião e mais liberal o de religiosidade, maior será o campo de exclusão para aqueles que veem como espúria a influência de valores religiosos nas decisões de agentes do Estado ${ }^{48}$. Podemos dizer que, em contrapartida, quanto menor o âmbito conceitual, maiores poderão ser as restrições nessa área ao exercício de direitos por iniciativa estatal, sob o argumento da inexistência de conflito com a garantia da liberdade religiosa.

age discriminations cases. Social Science Quarterly, v. 85, n. 1, mar. 2004. p. 10. (Tradução nossa).

47 "Os dados revelam que, em cada faixa etária, os Republicanos evidenciam menor probabilidade de proferir uma decisão 'liberal" do que os Democratas dentro da mesma faixa. Contudo, mesmo no âmbito de cada partido, a probabilidade de uma decisão 'liberal' aumenta na faixa etária dos mais idosos". MANNING Kenneth L.; CAROLL Bruce A; CARP, Robert A. Does age matter?: judicial decision making in age discriminations cases. Social Science Quarterly, v. 85, n. 1, mar. 2004. p. 14.

48 IDLEMAN, Scott C. The role of religious values in judicial decision making. Indiana Law Journal, v. 68, n. 2, article 3, 1993. p. 435. 
Parece-nos intuitivo incluir na categoria de religiosos todos aqueles valores professados por instituições que se autodenominam e que são popularmente reconhecidas como religiosas, fundadas ou inspiradas em uma crença teísta. A Igreja Católica, por exemplo, pregaria valores religiosos na medida em que seus dogmas seriam fundados na crença e na doutrina de um ser superior (Deus). Da mesma forma, também nos parece intuitivo classificar como religiosos aqueles valores que digam respeito às grandes questões do homem e da humanidade, a exemplo da origem e do sentido da vida, do amor ao próximo, da proteção do mais fraco, da perpetuação da espécie, da vida após a morte, do destino do mundo, da moral, entre outros.

A primeira opção conduz a um raciocínio que fundamenta a natureza religiosa dos valores, princípios e dogmas exclusivamente em sua origem, sem qualquer pertinência com o mérito ou conteúdo. Grandes e pequenas questões se equivaleriam, desde que confirmada a fonte por uma instituição organizada que se considere e seja reconhecida como religiosa, e cuja doutrina seja fundada na existência de um ser superior e absoluto. A segunda opção, reconhecendo um significado religioso às grandes questões, a despeito de como e de onde tenham surgido, traz em si o problema de como distinguir o elemento religioso do que seja essencialmente moral ou filosófico. Questões puramente filosóficas, mas de grande importância para a humanidade, se classificariam como religiosas segundo esse ponto de vista.

No afã de discutir tais problemas, Idleman traça um paralelo entre atividades religiosas e não religiosas a partir de aspectos que, a priori, serviriam para distingui-las. Evidencia, contudo, que as atividades compartilhariam os aspectos analisados independentemente de sua categorização ou não como religiosas. Em termos mais simples, afirma que a busca por definir o que seria religioso a partir de um rol de características - como a crença teísta, o uso de um ritual, o uso de textos sagrados, o conceito de prece ou meditação e a expectativa da revelação - resultaria infrutífera por dois motivos: em primeiro lugar, porque cada uma dessas características seria compartilhada por atividades religiosas e não religiosas, de forma que sua presença em determinada instituição não a tornaria, apenas por isso, religiosa; em segundo lugar, porque determinadas instituições reconhecidamente religiosas nem sempre reuniriam todas as características, de forma que sua ausência, por si só, não lhe excluiria a natureza religiosa ${ }^{49}$. Em qualquer caso, esse check list somente levaria a resultados equivocados.

Em uma abordagem mais inclusiva (procurando evitar o que chama de cristianismo-centrismo ou ocidente-centrismo), o mesmo autor refere-se à posição que categoriza como religioso aquilo que o sujeito clama como tal, a depender do quão intenso e valioso seja para si o significado da atividade, princípio, valor ou dogma em questão. Religiosas, portanto, seriam as preocupações máximas (ultimate concerns) do indivíduo, aquilo que, de tão importante e significativo, relegaria a um plano secundário todo o restante ${ }^{50}$.

O problema com tal raciocínio é que sua enorme abrangência conduziria à aceitação, como religiosos, de valores e atividades culturalmente havidos como não religiosos. Além disso, preocupações de absoluta relevância para determinadas religiões poderiam ser consideradas trivialidades pelas demais. Em uma nação multicultural e tolerante como o Brasil, seria inadmissível classificar como não relevantes determinados valores apenas pelo fato de não suscitarem, sob o ponto de vista das correntes religiosas principais, grandes preocupações da bumanidade. A necessária abertura motivada pela tolerância nos reconduziria à advertência de Idleman, pois ampliaria, significativamente, o universo de valores a serem excluídos do processo de tomada de decisão nos atos do poder público.

A preferência do autor ora examinado é pela adoção do conceito mais restrito de religião, fundado na natureza teísta da doutrina segundo a qual o valor seja afirmado, na autodeclaração e no reconhecimento social como religiosa da instituição que o professa. Com exceção de Idelman, os autores que trataram da temática dos valores religiosos e cujos textos foram analisados no presente trabalho não se dispuseram a tratar do conceito de religião. Ainda assim, parece-nos que a abordagem por eles conduzida não se diferencia da noção aqui apresentada, mas com ela se harmoniza nos limites da proposta que cada um assumiu, o que nos

49 IDLEMAN, Scott C. The role of religious values in judicial decision making. Indiana Law Journal, v. 68, n. 2, article 3, 1993 . p. 437.

50 IDLEMAN, Scott C. The role of religious values in judicial decision making. Indiana Law Journal, v. 68, n. 2, article 3, 1993. p. 438. 
conduz, quase necessariamente, a adotá-la como conceito de trabalho para os fins do estudo ora proposto ${ }^{51}$.

No que diz respeito às pesquisas empíricas sobre a influência dos valores religiosos do juiz no processo de tomada de decisão judicial, examinamos três significativos trabalhos sobre o tema, os quais relatam e criticam outras pesquisas empíricas, com a vantagem de que, referindo-se às vezes a um mesmo trabalho, esses autores nos permitiram comparar suas avaliações acerca dos dados e resultados, concedendo-nos a oportunidade de uma compreensão mais clara de suas ideias.

Em seu trabalho, Feldman trata da existência de dois tipos de estudos que investigaram as influências que a religião exerceria sobre a tomada de decisão ${ }^{52}$. O primeiro, mais geral, parte da psicologia social e assenta que o sentimento de pertencimento a determinado grupo social seria capaz de afetar o indivíduo em seus valores e percepções. Desse modo, o sujeito passaria a compartilhar os objetivos e visões de mundo do grupo a que se sente pertencer, ao mesmo tempo em que começaria a enxergar como inconciliáveis e, às vezes, antagônicos aqueles compartilhados por integrantes de grupos diversos.

A conclusão do autor aponta para o reconhecimento de uma tendência de decisão, no caso dos juízes e do processo de tomada de decisão, mais atrelada às visões de mundo, preferências, percepções e valores acolhidos em seu próprio meio social, o que pode implicar o repúdio aos interesses dos integrantes de grupos sociais diversos cujos valores não se identifiquem com os seus. A abordagem é visivelmente mais generalista, pois esse fundamento poderia explicar não apenas que juízes cristãos, por exemplo, sejam menos afeitos às pretensões de litigantes muçulmanos, mas também que juízes idosos sejam mais favoráveis aos pleitos de pessoas idosas, que juízes negros, de sua parte, sejam mais afeitos aos pleitos de minorias raciais etc.

Tratando dos tipos mais específicos de estudos sobre a influência da religião nas decisões judiciais, Feldman classifica-os, conquanto em pequeno número, conforme cuidem ou não de demandas relativas ao exercício da liberdade religiosa. Em ambos os tipos, afirma que os achados empíricos permitiram aos pesquisadores confirmar a hipótese de que a religião dos julgadores exerceria forte influência no resultado das decisões. Dos trabalhos examinados por Feldman, destacam-se os de Daniel R. Pinello ${ }^{53}$, analisando decisões relativas ao que denominou de "gay rights"; de Donald R. Songer e Susan J. Tabrizi ${ }^{54}$, que analisaram decisões singulares de juízes estaduais sobre pena de morte, discriminação de gênero e obscenidade ${ }^{55}$; e o trabalho de Gregory C. Sisk, Michael Heise e Andrew P. Morriss ${ }^{56}$, sobre a resolução de questões de liberdade religiosa em cortes inferiores federais.

51 O Supremo Tribunal Federal brasileiro, examinando pleito em que se demandava a aplicação da imunidade tributária dos templos de qualquer culto a uma loja maçônica do Rio Grande do Sul (Recurso Extraordinário n. 562.351/RS), optou por um conceito restritivo de religião e religiosidade, excluindo dessa forma o enquadramento das atividades ritualísticas da maçonaria do conceito de culto desenvolvido em um templo. O próprio relator, Ministro Ricardo Lewandowski, assentou que, em matéria de imunidade tributária, a exegese teria que ser necessariamente restritiva. Em interpretação sistemática da Constituição Federal, a maioria dos ministros entendeu pela aplicação da imunidade aos templos em que se desempenhassem cultos necessariamente religiosos, o que pressupunha o preenchimento de requisitos alheios aos rituais desenvolvidos pelos associados do demandante. Em divergência, o ministro Marco Aurélio entendeu que a maçonaria, considerados seus objetivos e a realização de seus rituais, se enquadraria no conceito de religião em um sentido amplo, pelo que se lhe aplicaria a imunidade. A definição do significado de religião e religiosidade, como se observa, também no Brasil está longe de ser pacífica.

52 FELDMAN, Stephen M. Empiricism, religion, and judicial decision-making. William \& Mary Bill of Rights Journal, v. 15, n. 1, 2006. Disponível em: <http://scholarship.law.wm.edu/cgi/viewcontent.cgi?article=1132\&context=wmborj>. Acesso em: 12 jun. 2018.

53 Gay Rights and American Law, de 2003.

54 Referenciado no texto como: SONGER, Donald R.; TABRIZI, Susan J. The religious right in court: the decision making of christian evangelicals in State supreme courts, v. 61 n. 507, 1999.

55 Esses dois trabalhos foram também analisados por Bornstein e Miller e, por isso, cuidaremos deles adiante. BORNSTEIN, Brian H.; MILLER, Monica K. Does a judge's religion influence decision making? Court Review: the Journal of the American Judges Association, paper 300, 2009.

56 Referenciado no texto como: Gregory C. Sisk et al., Searching for the Soul of Judicial Decision making: An Empirical Study of Religious Freedom Decisions, 65 OHIO ST. L.J. 491 (2004). No decorrer da pesquisa que levou à elaboração do presente trabalho, tivemos acesso ao texto dos autores, de modo que pudemos examiná-lo como fonte direta. Cf. SISK, Gregory C.; HEISE, Michael; MORRISS, Andrew P., Searching for the soul of fudicial decisionmaking: an empirical study of religious freedom decisions. Cornell Law Faculty Publications, paper 729, 2004. 
Nesse último trabalho, Sisk, Heise e Morriss, referindo-se, especificamente, às demandas pelo exercício da liberdade religiosa, apontam a religião — seja em termos de afiliação do reclamante, de formação do juiz ou de composição demográfica da comunidade — como o mais proeminente, destacado e consistente fator de influência sobre o processo de tomada de decisão encontrado em sua investigação ${ }^{57}$. O estudo sugere, entre outras proposições, que juízes judeus e cristãos ditos minoritários (ou seja, não vinculados às correntes principais do cristianismo) são significativamente mais susceptíveis ao acolhimento de pleitos relativos ao exercício da liberdade religiosa, ao passo que reclamantes provenientes de comunidades religiosas católicas e batistas seriam os menos suscetíveis de vitória ${ }^{58}$.

Alguns achados interessantes foram registrados por Sisk, Heise e Morriss, descritos também por Feld$\operatorname{man}^{59}$. De acordo com os primeiros, os integrantes de correntes religiosas principais demandariam significativamente menos pela garantia do exercício da liberdade religiosa do que aqueles pertencentes a grupos minoritários, o que se daria porque aqueles grupos majoritários dominariam as instâncias produtoras de normas, de modo que raramente enfrentariam limitações dessa natureza ao exercício de sua religião. Por outro lado, em termos estatísticos, os adeptos de grupos religiosos minoritários sairiam mais vencedores em suas demandas, o que estaria em harmonia com dois estudos anteriores, de Frank Way e Barbara J. Burt, como também de Joseph A. Ignagni, igualmente examinados por Feldman ${ }^{60}$.

Nesses casos particulares, os demandantes pleiteavam providências contra o Estado para a garantia da liberdade religiosa em suas possíveis formas de expressão. Considerando esse aspecto, os resultados acima relatados nos parecem lógicos, na medida em que a natureza e o alcance da liberdade religiosa sejam explícita ou implicitamente definidos pelo direito objetivo, produto natural dos valores inerentes à sociedade, sobretudo daquela parcela que, compondo o grupo majoritário, imprime ao direito positivo seus próprios valores. A influência dos valores religiosos, nesse caso, se faria sentir já no processo de produção de normas gerais e abstratas, o que não implicaria sua ausência dos tribunais. Ao contrário, essa influência repercutiria vivamente em decisões de juízes adeptos de correntes religiosas minoritárias, os quais se revelariam mais receptivos a demandas pela garantia da liberdade.

Mais interessante, em nosso sentir, é a temática da influência dos valores religiosos em demandas sobre temas eminentemente seculares, ou seja, compreendendo questões nitidamente não religiosas. Bornstein e Miller ${ }^{61}$ afirmam a existência de estudos empíricos que teriam comparado posturas de juízes católicos e protestantes em casos não unânimes sobre determinada variedade de casos-tipos pré-definidos. Alguns desses estudos foram igualmente examinados por Feldman.

Analisando quinze espécies de demandas, Stuart S. Nagel ${ }^{62}$ teria detectado um padrão de decisão nitida-

57 "Em nosso estudo sobre decisões em matéria de liberdade religiosa, o mais proeminente, saliente e consistente fator de influência no processo de tomada de decisão judicial foi a religião — religião em termos de afiliação do demandante, a formação do juiz e o perfil demográfico da comunidade" SISK, Gregory C.; HEISE, Michael; MORRISS, Andrew P., Searching for the soul of fudicial decisionmaking: an empirical study of religious freedom decisions. Cornell Law Faculty Publications, paper 729, 2004. p. 614. (Tradução nossa).

58 “Talvez os mais notáveis achados, os quais são discutidos adiante, foram que juízes de formação judaica e cristã da corrente minoritária se revelaram mais propensos ao acolhimento de demandas por acomodação, enquanto que demandantes de comunidades religiosas católicas e batistas foram significativamente menos propensos ao sucesso em suas pretensões” SISK, Gregory C.; HEISE, Michael; MORRISS, Andrew P., Searching for the soul of fudicial decisionmaking: an empirical study of religious freedom decisions. Cornell Law Faculty Publications, paper 729, 2004. p. 557. (Tradução nossa).

59 FELDMAN, Stephen M. Empiricism, religion, and judicial decision-making. William \& Mary Bill of Rights Journal, v. 15, n. 1, 2006. Disponível em: <http://scholarship.law.wm.edu/cgi/viewcontent.cgi?article=1132\&context=wmborj $>$. Acesso em : 12 jun. 2018.

60 Referenciados no texto de Feldman como: Frank Way \& Barbara J. Burt, Religious Marginality and the Free Exercise Clause, 77 AM. POL. SCI. REV. 652 (1983) e Joseph A. Ignagni, U.S. Supreme Court Decision-Making and the Free Exercise Clause, 55 REv. POL 511 (1993).

61 BORNSTEIN, Brian H.; MILLER, Monica K. Does a judge's religion influence decision making? Court Review: the Journal of the American Judges Association, paper 300, 2009.

62 Referenciado no texto como: Stuart S. Nagel, "The Relationship Between the Political and Ethnic Affiliation of Judges, and Their Decision-making," in: Judicial behavior: a reader in theory and research (G. Schubert ed., 1964). O objetivo da pesquisa estava em 
mente liberal nos julgamentos proferidos por juízes católicos em quatro espécies de demandas (demandas criminais, regulações negociais, divórcio e danos ao empregado), em contraste com o que afirmou ser a ausência de qualquer tendência decisória por parte dos julgadores protestantes em todas as espécies investigadas. $\mathrm{O}$ autor ainda registrou a ressalva de que a pequena quantidade de juízes judeus não lhe permitira a inclusão dos resultados para efeitos estatísticos.

Em sua pesquisa, Sheldon Goldman ${ }^{63}$ teria constatado que, em geral, julgadores católicos apresentaram uma tendência claramente favorável à causa de pessoas lesadas e dos economicamente vulneráveis. Malgrado a pequena quantidade de juízes judeus, sua média revelara uma tendência ainda mais liberal que a dos magistrados católicos e protestantes em todos os tipos de demandas. Os julgadores protestantes, de sua parte, em momento algum se revelaram mais liberais em qualquer tipo de causa, sugerindo o pesquisador que a religião não influiria em sua orientação decisória.

Os dois trabalhos a seguir foram examinados por Feldman e por Bornstein e Miller. No primeiro, que tivera por base julgados proferidos por tribunais de apelação entre os anos de 1981 e 2000 sobre questões compreendidas no conceito de "gay rights" ${ }^{\circ 4}$, Daniel R. Pinello afirma que, em geral, constatou-se uma tendência relativamente liberal de juízes judeus em comparação com juízes protestantes, como também uma tendência mais conservadora de juízes católicos nessas questões ${ }^{65}$.

No segundo, Donald R. Songer e Susan J. Tabrizi examinaram votos de juízes em cortes supremas estaduais entre 1970 e 1993, especificamente em três questões: pena de morte, discriminação de gênero e obscenidade. Mesmo após o controle de outras variáveis, os autores afirmaram que a religião dos julgadores estaria fortemente associada a suas decisões. De acordo com os resultados, juízes evangélicos se mostraram significativamente mais conservadores ${ }^{66}$ que os adeptos das demais religiões nas três espécies de causas. $\mathrm{Na}$ outra ponta, os juízes judeus se apresentaram como os mais liberais. Juízes das correntes protestantes principais se revelaram liberais em casos de pena de morte e obscenidade, mas conservadores (embora não tanto quanto os evangélicos) nos de discriminação de gênero. Juízes católicos se apresentaram como liberais em questões de discriminação de gênero, moderados nos casos de pena de morte e quase tão conservadores quanto os juízes evangélicos nos casos de obscenidade.

Nesse ponto, é impossível não perceber a mudança de comportamento decisório de juízes católicos conforme o tema objeto de decisão. Tanto Stuart Nagel quanto Sheldon Goldman compararam as decisões de juízes católicos, protestantes e judeus em uma pluralidade de casos, concluindo que católicos e judeus seriam mais liberais e, portanto, mais pró-autores que juízes protestantes, sempre mais conservadores. A partir do trabalho de Daniel Pinello, percebemos que não existe uma correspondência rígida que vincule católicos e judeus ao conceito de liberal e protestantes ao de conservador. A investigação de Pinello, envolvendo questões de liberdade sexual, revelou que juízes católicos podem ser mais conservadores que juízes protestantes, tudo a depender do objeto da discussão e decisão. Essa conclusão, por fim, é corroborada pelos estudos de Do-

investigar a relação entre decisões judiciais e a religião dos juízes. Para isso, foram analisados julgados de 313 juízes de cortes supremas estaduais e federais no ano de 1955.

63 Referenciado no texto como: Sheldon Goldman, Voting Behavior on the United States Courts of Appeals Revisited, 69 AMER. POL. SCI. REV. 491 (1975). Afirma que foram comparadas decisões proferidas por juízes de apelação católicos e protestantes, usando o pesquisador como base de dados decisões das Cortes de Apelação de 1965 a 1971.

64 "Os casos compreendiam questões de famílias lésbicas/gays (inclusive casamento de pessoas de mesmo sexo), discriminação por orientação sexual, gays nas forças armadas, sodomia consensual e legislação de solicitação e liberdade de expressão e associação" (Tradução nossa). BORNSTEIN, Brian H.; MILLER, Monica K. Does a judge's religion influence decision making? Court Review: the Journal of the American Judges Association, paper 300, 2009. p. 113.

65 Podemos citar, como exemplos de julgados brasileiros em tribunais superiores sobre a mesma temática: ADPF 132/RJ, ADI 4277/DF, RESP 1183378 (união homoafetiva), RESP 1333086, RESP 1281093 , RESP 889852 (adoção em família homoafetiva), RESP 1302467 (alimentos), RE-AgR 607562, RESP 932653 (pensão por morte).

66 Ou seja, "eles mais frequentemente votaram pela aplicação da pena de morte, manutenção da distinção de gênero e restrição à liberdade de expressão em casos de obscenidade” BORNSTEIN, Brian H.; MILLER, Monica K. Does a judge’s religion influence decision making? Court Review: the Journal of the American Judges Association, paper 300, 2009. p. 114. (Tradução nossa). 
nald Songer e Susan Tabrizi, figurando juízes católicos, conforme o caso a decidir, como liberais, moderados ou até conservadores.

Considerando o quanto ainda dependemos de novos estudos empíricos sobre o tema, é no mínimo honesto dizer que quaisquer conclusões formadas no presente trabalho só podem ser provisórias. A despeito disso, e tomando por base todos os trabalhos aqui examinados, ousamos concluir afirmativamente pela existência de fortes indícios de que os valores religiosos do julgador - na medida em que componham o conjunto de valores e princípios integradores de sua identidade, formadores de seu caráter e definidores de seu modo de ver o mundo - exerçam significativa influência em seu processo de tomada de decisão, interferindo e, até mesmo, condicionando o resultado de seus julgamentos.

\section{SíNTESE CONCLUSIVA}

Como processo mental, a atividade de tomar decisões desenvolve-se no dispositivo psíquico humano e, por conta disso, expõe-se ao magnífico conjunto de influências historicamente cristalizadas na identidade e no caráter do indivíduo. Nesse ambiente, apenas parte do raciocínio que conduz ao resultado transita e trabalha com elementos que estão sobre a linha consciente: a maior parte do trajeto e dos influxos com os quais tem de lidar permanece oculta no misterioso universo do inconsciente humano. Toda decisão, portanto, é apenas em parte racional e consciente.

Isso nos permite explicar por que a neutralidade judicial - algo como uma blindagem ética e valorativa, uma despersonalização, uma fuga da história de vida e dos influxos emocionais que ela carrega — não existe como fato no mundo. Todo ser humano tem uma identidade, construída ao longo da vida, a partir de tudo quanto se insira em sua história: seus sucessos e fracassos, medos e realizações, em toda sua intensidade. Ao decidir, o juiz se transfigura para a decisão, que passa a existir com seu "DNA", com ele se identificando ao ponto de compartilharem os mesmo defeitos, qualidades, inclinações e preconceitos. Se é certo que cabe ao juiz buscar o valor do justo no ato de decidir e colocá-lo acima de suas manias e preferências, não menos certo que jamais conseguirá se neutralizar como ser humano.

A influência dessa gama de fatores que compõem a identidade e o caráter do juiz, formando-lhe a personalidade e atuando na construção de seus critérios de decisão e dos filtros por meio dos quais enxerga o mundo, tem despertado a atenção de pesquisadores interessados em saber até que ponto o processo de tomada de decisão pode sofrer seus efeitos. Conquanto iniciativas desse tipo ainda sejam uma grave lacuna na cultura brasileira, há, sobre o tema, estudos publicados fora do Brasil de indiscutível relevância.

No presente trabalho, procuramos examinar estudos empíricos que investigaram a possível influência de inclinações implícitas, da idade e dos valores religiosos de juízes para os resultados de suas decisões. Como vimos, os resultados apontaram, fortemente, para a constatação de que tais influxos desempenham um importante papel no processo de tomada de decisão, chegando a fornecer, em alguns casos típicos, validade preditiva. A despeito dos quanto tais estudos nos tenham permitido avançar, nossa única certeza é que a necessidade de pesquisas empíricas nessa área permanece tão atual quanto a insignificância de nosso conhecimento sobre a vastidão do universo psicológico, emocional e intelectivo do ser humano.

\section{REFERÊNCIAS}

ALMEIDA, Bruno Rotta; ALBRECHT, Diego Alan Schöfer; BAGATINI, Júlia. O juiz e as motivações no ato de julgar: para além das legais. Revista do Departamento de Ciências Jurídicas e Sociais da UNIJUÍ, Ijuí, ano. 20, n. 35, p. 75-99, jan./jun. 2011. 
BORNSTEIN, Brian H.; MILLER, Monica K. Does a judge's religion influence decision making? Court Review: The Journal of the American Judges Association, paper 300, 2009.

BRASIL. Supremo Tribunal Federal. Agravo regimental. Agravo regimental no recurso extraordinário com agravo 866.422/RJ. Segunda turma. Relator: min. Celso de Mello, Agte.(s): Loja Rosacruz Rio de Raneiro AMORC, Adv.(a/s): Artur Miranda de Sá e Silva e outro (a/s), Agdo.(a/s): município do Rio de Janeiro, Proc.(a/s)(es): procurador -geral do município do Rio de Janeiro. Brasília, 24 de março de 2015. Disponível em: <http://redir.stf.jus.br/paginadorpub/paginador.jsp?docTP $=$ TP\&docID=8255429>. Acesso em: 12 jun. 2018.

DINAMARCO, Cândido Rangel. A instrumentalidade do processo. 5. ed. São Paulo: Malheiros, 1996.

DINAMARCO, Cândido Rangel. Fundamentos do processo civil moderno. 5. ed. São Paulo: 2002. v.1.

DINAMARCO, Cândido Rangel. Instituições de direito processual civil. 4. ed. São Paulo: Malheiros, 2004. v.1.

FELDMAN, Stephen M. Empiricism, religion, and judicial decision-making. William \& Mary Bill of Rights Journal, v. 15, n. 1, 2006. Disponível em: <http://scholarship.law.wm.edu/cgi/viewcontent.cgi?article=1132 \&context=wmborj>. Acesso em: 12 jun. 2018.

FERNANDES, Ricardo Vieira de Carvalho. As influências extrajurídicas sobre as decisões do Supremo Tribunal Federal. Revista jurídica da Procuradoria-Geral do Distrito Federal, Brasília, v. 38, p. 95-112, 2012.

FREUD, Sigmund. Freud 1923-1925 o en e o id, autobiografia e outros textos: obras completas. São Paulo: Companhia das Letras, 2011. v. 16.

GIACOMOLLI, Nereu José; DUARTE, Liza Bastos. O mito da neutralidade na motivação das decisões judiciais: aspectos epistemológicos. Revista da AJURIS, v. 33, n. 102, jun. 2006.

GOUVEIA, Lúcio Grassi de. A função legitimadora do princípio da cooperação intersubjetiva no processo civil brasileiro. Revista de Processo, São Paulo, v. 172, p. 32-53, jun. 2009.

GRIFFEN, Wendell L. The case for religious values in judicial decision-making, Marq. L. Rev, v. 81, n. 513, 1998.

GUTHRIE, Chris; RACHLINSKI, Jeffrey J.; WISTRICH, Andrew J. Blinking on the bench: how judges decide cases. Cornell Law Faculty Publications, paper 917, 2007.

IDLEMAN, Scott C. The role of religious values in judicial decision making. Indiana Law Journal, v. 68, n. 2, article 3, 1993.

IRWIN, John F.; REAL Daniel L. Unconscious influences on judicial decision-making: the ilusion of objectivity. McGeorge L. Rev. v. 42, n. 1, 2010-2011.

JUNG, Carl Gustav. Man and his symbols. Random House Publishing Group, 2012.

KELSEN, Hans. Teoria pura do direito. Trad. João Baptista Machado. 7. ed. São Paulo: M. Fontes, 2006.

LOPES JÚNIOR, Aury. Introdução crítica ao processo penal: fundamentos da instrumentalidade constitucional. 4. ed. Rio de Janeiro: Lumen Juris, 2006.

MANNING Kenneth L.; CAROLL Bruce A; CARP, Robert A. Does age matter?: judicial decision making in age discriminations cases. Social Science Quarterly, v. 85, n. 1, mar. 2004.

PAMPLONA FILHO, Rodolfo. O mito da neutralidade do juiz como elemento de seu papel social. Ciência Jurídica, ano. 12, v. 81, p. 32-45, maio/jun. 1998.

RODRIGUEZ, José Rodrigo. Como decidem as cortes?: para uma crítica do direito (brasileiro). Rio de Janeiro: FGV, 2013. 
SISK, Gregory C.; HEISE, Michael; MORRISS, Andrew P., Searching for the soul of fudicial decisionmaking: an empirical study of religious freedom decisions. Cornell Law Faculty Publications, paper 729, 2004.

SONGER, Donald R.; TABRIZI, Susan J. The religious right in court: the decision making of christian evangelicals in State supreme courts, v. 61 n. 507, 1999. 
Para publicar na revista Brasileira de Políticas Públicas, acesse o endereço eletrônico www.rbpp.uniceub.br

Observe as normas de publicação, para facilitar e agilizar o trabalho de edição. 